\title{
HOCl-modified phosphatidylcholines induce apoptosis and redox imbalance in HUVEC-ST cells
}

Agnieszka Robaszkiewicz, Grzegorz Bartosz, Andrew R. Pitt, Alpesh Thakker, Richard A. Armstrong, Corinne M. Spickett ${ }^{\#}$,Mirosław Soszyński ${ }^{\#}$

Agnieszka Robaszkiewicz - corresponding author, Department of EnvinmentalPolution Biophysics, Faculty of Biology and Environmental Protection, University of Łódź, Pomorska 141/143, 90-236 Łódź; e-mail: robaszkiewicz.agnieszkaz@gmail.com, tel: +48-42-6354449, fax: +48-42-6354475, mailing address: Department of Envinmental Polution Biophysics, Faculty of Biology and Environmental Protection, University of Łódź, Pomorska 141/143, 90236 Łódź;

Grzegorz Bartosz- Department of Molecular Biophysics, Faculty of Biology and Environmental Protection, University of Łódź, Pomorska141/143, 90-236 Łódź, Poland, Department of Biochemistry and Cell Biology, University of Rzeszów, St. Pigonia 6, 35-959 Rzeszów, Poland, e-mail: grzegorz.bartosz@gmail.com

Andrew R. Pitt - School of Life and Health Sciences, Aston University, Aston Triangle, Birmingham, B4 7ET, UK, e-mail: a.r.pitt@aston.ac.uk

Alpesh Thakker - School of Life and Health Sciences, Aston University, Aston Triangle, Birmingham, B4 7ET, UK, e-mail: thakkera@aston.ac.uk

Richard A. Armstrong - Ophthalmic Research Group, School of Life and Health Sciences, School of Optometry, Aston University, Aston Triangle, Birmingham, B4 7ET, UK, e-mail: r.a.armstrong@aston.ac.uk

Corinne M. Spickett - (joint senior author) School of Life and Health Sciences, Aston University, Aston Triangle, Birmingham, B4 7ET, UK, e-mail: c.m.spickett@aston.ac.uk

Mirostaw Soszyński - Department of Molecular Biophysics, Faculty of Biology and Environmental Protection, University of Łódź, Pomorska 141/143, 90-236 Łódź, Poland, email: sosmirek@biol.uni.lodz.pl

\# - joint senior authorship 


\begin{abstract}
Electrophilic attack of hypochlorous acid on unsaturated bonds of fatty acyl chains is known to result mostly in chlorinated products that show cytotoxicity to some cell lines and were found in biological systems exposed to $\mathrm{HOCl}$. This study aimed to investigate more deeply the products and the mechanism underlying cytotoxicity of phospholipid-HOCl oxidation products, synthesized by the reaction of $\mathrm{HOCl}$ with 1-stearoyl-2-oleoyl-, 1-stearoyl-2linoleoyl-, and 1-stearoyl-2-arachidonyl-phosphatidylcholine. Phospholipid chlorohydrins were found to be the most abundant among obtained products. HOCl-modified lipids were cytotoxic towards HUVEC-ST (endothelial cells), leading to a decrease of mitochondrial potential and an increase in the number of apoptotic cells. These effects were accompanied by an increase of the level of active caspase- 3 and caspase-7, while the caspase-3/-7 inhibitor AcDEVD-CHO dramatically decreased the number of apoptotic cells. Phospholipid-HOCl oxidation products were shown to affect cell proliferation by a concentration-dependent cell cycle arrest in the $G_{0} / G_{1}$ phase and activating redox sensitive p38 kinase. The redox imbalance observed in HUVEC-ST cells exposed to modified phosphatidylcholines was accompanied by an increase in ROS level, and a decrease in glutathione content and antioxidant capacity of cell extracts.
\end{abstract}

Supplementary keywords: phosphatidylcholine, hypochlorous acid, apoptosis, redox imbalance, atherosclerosis 


\section{Introduction}

Programmed cell death is documented to be involved in the initiation and the course of many human diseases; for example, endothelial apoptosis and perturbation have been found in allograft vasculopathy, hypertension, congestive heart failure, primary pulmonary hypertension and sepsis [1]. This process is also thought to contribute in the formation of atherosclerotic plaques in the early stages of atherosclerosis [2-4]. Apoptotic endothelial cells have been demonstrated to release IL-1 and adhesion molecules, as well as to have reduced production of NO and prostacyclins, leading to platelet and neutrophil activation [1]. A number of reports have suggested that oxidatively-modified low density lipoproteins (oxLDL) are pro-apoptotic factors and can be considered as one of the many risk factors in atherosclerosis $[5,6]$. In particular, modifications of the protein and lipids of the LDL fraction accelerate its uptake by macrophages, resulting in conversion of these cells into foam cells [7, 8]. Oxidation of LDL components has been attributed to the action of reactive oxygen and nitrogen species, released mainly by activated phagocytic cells. However, the presence of active myeloperoxidase in the atherosclerotic plaques and the detection of 3-chlorotyrosine residues have attracted the attention to the possible role of another oxidant, hypochlorous acid (HOCl) $[9,10]$.

$\mathrm{HOCl}$ generated during the oxidation of $\mathrm{Cl}^{-}$by $\mathrm{H}_{2} \mathrm{O}_{2}$ catalysed by myeloperoxidase (MPO), mainly inside activated neutrophils, but many data indicate the biological and pathogenic role of this enzyme outside phagocytes $[11,12]$. The reaction of $\mathrm{HOCl}$ with biological molecules produces a wide spectrum of oxidized and chlorinated products [13]. The presence of lipid and fatty acid chlorohydrins (alpha-chloro, beta-hydroxy derivatives) among the products found after red blood cell treatment with $\mathrm{HOCl}$ was demonstrated by studies using thin layer chromatography (TLC) and antibodies [14]. Jerlich and co-workers used electrospray mass spectrometry to identify chlorohydrins of phosphatidylcholines in LDL following oxidation with $\mathrm{HOCl}$ or the myeloperoxidase system, and found that chlorohydrins are the major products formed at low $\mathrm{HOCl}$ concentrations [15]. The biological significance and possible role of phospholipid chlorohydrins in the pathogenesis of atherosclerosis have been demonstrated recently by Messner et al., who showed the presence of lysophosphatidylcholine chlorohydrins in atherosclerotic plaques [16]. Recently, fatty acid chlorohydrins have been found in plasma $(2-4 \mu \mathrm{M})$ and white adipose tissue $(0.5-4 \mathrm{nmol} / \mathrm{mg})$ with especially high levels in ascetic fluid $(50-250 \mu \mathrm{M})$ during acute pancreatitis [17]. Although the levels of 
phospholipid chlorohydrins in vivo were not investigated in this study, it is likely that correspondingly high levels would also occur in several inflammatory conditions.

Several studies have reported adverse effects of fatty acid and phospholipid chlorohydrins on cells. Early work showed that pre-formed fatty acid chlorohydrins caused lysis of red blood cells, which was thought to involve a physical disruption of the membrane [14]. Our recent work on this topic has demonstrated that phospholipid chlorohydrins are taken up more rapidly than the corresponding unmodified lipids by red blood cells, and incorporated into the membrane [18]. Phospholipid chloro- and bromohydrins were found to cause toxicity to human umbilical vein endothelial cells (HUVECs), determined by leakage of chromium from the cells [19], while in cultured myeloid cells several phospholipid chlorohydrins were observed to cause deletion of ATP and loss of viability according to the MTT assay [20]. At lower concentrations, production of reactive oxygen species by chlorohydrin-treated splenocytes and increased of adherence of splenocytes to chlorohydrin-treated artery segments was observed. However, there is some controversy over the mechanism by which phospholipid chlorohydrins may cause cell death. Vissers et al. (2001) concluded that the mechanism was necrotic, based on a lack of annexin V binding to chlorohydrins-treated HUVECs, whereas Deveret al. (2006) reported that chlorohydrins caused an increase in the levels of active caspase-3, suggesting that apoptosis occurred at least at certain chlorohydrin concentrations [19,21].

The current study was therefore undertaken to investigate in more depth the potential of phospholipid-HOCl oxidation products to act as pro-apoptotic and anti-proliferative factors for endothelial cells, as this could contribute to the loss of the endothelial monolayer in early stages of atherosclerosis. Our study included also the effect of HOCl-modified phosphatidylcholines on the intracellular redox state and activation of the key redox sensitive kinase $\mathrm{p} 38$, which is implicated in many cellular processes (e.g. apoptosis induction and cell cycle progression). As mentioned above, phosphatidylcholine chlorohydrins (which are demonstrated in the current study and previously published papers $[15,18,20]$ as major products of the reaction between $\mathrm{HOCl}$ and phosphatidylcholines) were shown to induce ROS production in splenocytes, thereby acting as less reactive but long-lasting mediators of $\mathrm{HOCl}$ oxidative action. Immortalized Human Umbilical Vein Endothelial Cells (HUVEC-ST) were used as a model cells.1-stearoyl-2-oleoyl-, 1-stearoyl-2-linoleoyl-, and 1-stearoyl-2arachidonyl-phosphatidylcholinewere exposed to $\mathrm{HOCl}$ as described previously, and the products were subjected to more precise analysis (MS/MS and NMR) in order to confirm high abundance of lipid chlorohydrins in the mixture of HOCl-modified products [18]. 


\section{Materials and Methods}

\section{Materials:}

Annexin V: FITC Apoptosis Detection Kit I and rabbit, FITC-conjugated anti-caspase-3 monoclonal antibody were purchased from Becton Dickinson Pharmingen (Warsaw, Poland). 3-(4,5-Dimethyl-2-thiazolyl)-2,5-diphenyl-2H-tetrazolium bromide (MTT), ethidiumbromide, ribonuclease-A, hypochlorite, Mitochondria Staining Kit from Sigma Aldrich (Poznań, Poland). 1-stearoyl-2-oleoyl-sn-glycero-3-phosphocholine (SOPC), 1-stearoyl-2-linoleoyl-snglycero-3-phosphocholine (SLPC), 1-stearoyl-2-arachidonoyl-sn-glycero-3-phosphocholine (SAPC), 1,2-dipalmitoyl-sn-glycero-3-phosphoethanolamine-N-(7-nitro-2-1,3-benzoxadiazol4-yl) ammonium salt (NBD-phosphatidylethanolamine) and polycarbonate membranes $(0.1 \mu \mathrm{m})$ were purchased from Avanti Polar Lipids (Delfzyl, Netherlands), and Sep-Pak ${ }^{\circledR}$ Plus C18 cartridges were from Waters (Warsaw, Poland). Dulbecco's Modified Eagle Medium with Glutamax-I, sodium pyruvate and glucose (DMEM), OptiMEM, fetal bovine serum (FBS) and penicillin/streptomycin solution were from Invitrogen (Warsaw, Poland), while Cell-Based ELISA for p38 phosphorylation from R\&D (UK).

The HUVEC-ST (Human Umbilical Vein Endothelial Cells immortalized by transfection with both SV40 large/small T antigens and the catalytic subunit of human telomerase) cell line was obtained from Dr. Claudine Kieda (University of Orleans, France), but established and characterized at University of Rome Tor Vergata as described by Tentori et al [22]). The cells were tested periodically for mycoplasm.

\section{Synthesis of lipid chlorohydrins}

HOCl-modified phospholipids were synthesized as described in our previous paper [18]. Briefly, multilamellar lipid vesicles $(10 \mathrm{mg} / \mathrm{ml})$ were obtained by $1 \mathrm{~min}$ vortexing of a lipid film with Hank's Buffered Salt Solution, followed by sonication at $37^{\circ} \mathrm{C}$ for $15 \mathrm{~min}$ and a further 1 min vortexing. Afterwards, the phospholipid suspension was subjected to $\mathrm{HOCl}$ treatment at pH 6.0 (5 molar excess of oxidant per one double bond) at $37^{\circ} \mathrm{C}$ for $30 \mathrm{~min}$. The excess $\mathrm{HOCl}$ was removed by passing the mixture through a reverse phase Sep-pak cartridges and washing with water (use of the Sep-pak cartridges does not significantly alter the phospholipid profiles of the preparation and previous work demonstrated that lipid effects cannot be attributed to contaminants leaked from the cartridges). Lipids were recovered by successive application of methanol, chloroform: methanol (1:1) and chloroform, and organic solvents were evaporated under argon. The purification process did not affect composition of either unmodified lipids or chlorohydrins. Liposomes added to cell cultures were 
reconstructed in PBS from the total amount of purified, modified phosphatidylcholines (chlorohydrins were not separated from the other oxidation products, which occurred in far lower extent). Prior to addition to cell culture, the suspension of liposomes was subjected to 21 cycles of extrusion (polycarbonate membrane $0.1 \mu \mathrm{m}$ ) in order to obtain unilamellar liposomes [23]. As purification of phospholipid- $\mathrm{HOCl}$ oxidation products from the excess of unbound hypochlorous acid followed by liposome reconstitution from organic solvents may result in the loss of lipids, the concentration of phospholipids was quantified each time with ammonium ferrithiocyanate [24]. Unmodified, non-purified lipids were used as appropriate controls.

To confirm further the conversion of intact unsaturated lipids into phosphatidylcholine chlorohydrins we additionally subjected phospholipid-HOCl oxidation products to MS/MS (tandem MS), facilitated by the use of precursor-ion scanning and neutral-loss and ${ }^{1} \mathrm{H}-\mathrm{NMR}$, as described in supplementary information.

The incorporation of liposomes into HUVEC-ST cells was analyzed using NBD-labeled liposomes prepared according to a previously described method [18], which were added to cells (plated the day before the experiment on a black 96-well plate) and incubated for selected time periods. After three cycles of washing with PBS, fluorescence was measured at $485 / 538 \mathrm{~nm}$.

\section{Cell growth and treatment}

HUVEC-ST cells were cultured in OptiMEM supplemented with $2 \%$ FBS, $50 \mathrm{U} / \mathrm{ml}$ penicillin and $50 \mu \mathrm{g} / \mathrm{ml}$ streptomycin $\left(37^{\circ} \mathrm{C}, 5 \% \mathrm{CO}_{2}\right)$ [25, 26]. For each experiment, cells were seeded $24 \mathrm{~h}$ before liposome addition at the density of 440 cells $/ \mathrm{mm}^{2}$ (which corresponds to 5000 cells per well on a 96-well plate). The cell density and lipid: cell ratio was the same in all experiments. Liposome suspension in PBS was added to the growth medium in which the cells were being cultured and immediately mixed gently.

\section{Determination of cytotoxicity}

The cytotoxicity of unmodified and modified phosphatidylcholines in the culture of HUVECST cells was estimated on the basis of the DNA content, which corresponds to cell number. After $24 \mathrm{~h}$ cell incubation with lipids or lipid chlorohydrins on a 96-well black plate, cells were washed, lysed, RNA was digested with RNAse and remained DNA was stained with propidium iodide as described previously [27].

\section{Determination of mitochondrial potential}

Mitochondrial potential was estimated using the JC-1-based Mitochondria Staining Kit (Sigma Aldrich, Poznań, Poland) according to the manufacturer's instructions. Fluorescence 
was measured using a LSR II Flow Cytometer and the ratio between red (FL-2) and green (FL-1) fluorescence corresponded to the mitochondrial potential [28]. Valinomycin (0.1 $\mu \mathrm{g} / \mathrm{ml}$ ) was used as a positive control for dissipating membrane potential [29].

\section{Detection of apoptosis and necrosis}

Annexin V: FITC Apoptosis Detection Kit was employed for quantification of the apoptotic and necrotic cell population after $6 \mathrm{~h}$ cell incubation with liposomes. The procedure of staining was carried out according to the instructions provided by the manufacturer. Cell fluorescence was analyzed in an LSR II BD Flow Cytometer. Cells emitting weak green and weak red fluorescence were classified as living (L), those emitting strong green and weak red fluorescence as early apoptotic (EA), cells emitting strong green and strong red as late apoptotic (LA), and those emitting weak green and strong red fluorescence as necrotic (N) $[30,31]$.

To confirm the contribution of caspase- 3 and caspase-7 to apoptosis evoked by liposomes, cell incubation with liposomes was preceded with a $1 \mathrm{~h}$ cell pre-treatment with the caspase- 3 and caspase-7 inhibitor - Ac-DEVD-CHO $(10 \mu \mathrm{M})$. The presence of the caspase inhibitor alone did not affect cell viability (data not shown).

\section{Determination of caspase-3 and caspase-7 active forms}

After $6 \mathrm{~h}$ incubation the cells were trypsinized, fixed with cold $1 \%$ formaldehyde in PBS on ice for $15 \mathrm{~min}$, permeabilized in $0.1 \%$ Tween in PBS at $37^{\circ} \mathrm{C}$ for $30 \mathrm{~min}$ and stained with the FITC-conjugated anti-caspase-3 antibody for $1 \mathrm{~h}$. For estimation of active caspase-7 the combination of primary anti-caspase-7 $(10 \mu \mathrm{g} / \mathrm{ml}, 1 \mathrm{~h}$, room temperature $)$ and secondary FITC-conjugated antibody ( $4 \mu \mathrm{g} / \mathrm{ml}, 1 \mathrm{~h}$, room temperature) was used. Cells were washed 4 times with a 10-fold excess of $1 \%$ BSA in PBS to remove the excess of unbound antibodies. The fluorescence of the cells was read on a LSR II Flow Cytometer at excitation $488 \mathrm{~nm}$, emission $530 \mathrm{~nm}$.

\section{Cell staining with Hoechst 33342}

After $6 \mathrm{~h}$ incubation with parent or HOCl-oxidized phosphatidylcholines $(100 \mu \mathrm{M})$, the cells were washed twice with PBS and stained with $10 \mu \mathrm{M}$ Hoechst 33342 in PBS for 15 min at $37^{\circ} \mathrm{C}$ in the dark. Cells were observed using a fluorescence microscope (Olympus IX70, Japan; magnification 40x) and were discriminated on the basis of intensity of fluorescence and chromatin structure: cells emitting no fluorescence were recognized as living, those emitting strong, bright fluorescence and demonstrating condensation of chromatin as early apoptotic, cells with bright chromatin distributed to apoptotic bodies as late apoptotic [32, 33]. 


\section{Analysis of the cell cycle}

The proliferation ability of cells incubated with liposomes for $24 \mathrm{~h}$ was estimated on the basis on the intracellular DNA content as described previously [27]. The fluorescence of cells stained with propidium iodide was read in an LSR II BD Flow Cytometer at excitation 488 $\mathrm{nm}$ and emission $633 \mathrm{~nm}$. Cell distribution in $\mathrm{G}_{0} / \mathrm{G}_{1}, \mathrm{~S}$ and $\mathrm{G}_{2} / \mathrm{M}$ phases was analyzed with FlowJo software [34].

\section{Measurement of reactive oxygen species production}

After $1 \mathrm{~h}$ incubation with liposomes, cells were washed three times with PBS and stained with $5 \mu \mathrm{M}$ dihydrorhodamine 123 at $37^{\circ} \mathrm{C}$ for $30 \mathrm{~min}$. Cell fluorescence was measured in an LSR II Becton Dickinson Flow Cytometer at excitation $488 \mathrm{~nm} /$ emission $530 \mathrm{~nm}$.

The production of superoxide anion by mitochondria was estimated on the basis of MitoSOX Red oxidation. Briefly, cells incubated with liposomes for $1 \mathrm{~h}$ were washed once with PBS and stained with the above-mentioned fluorescent probe $(5 \mu \mathrm{M})$ at $37{ }^{\circ} \mathrm{C}$ for $15 \mathrm{~min}$. The excess of probe was removed in three cycles of cell washing with PBS and cells were incubated at $37^{\circ} \mathrm{C}$ for further $30 \mathrm{~min}$. Cell fluorescence was measured in an LSR II Becton Dickinson Flow Cytometer at excitation $488 \mathrm{~nm} /$ emission $575 \mathrm{~nm}$.

\section{Determination of intracellular glutathione}

The intracellular content of glutathione after $1 \mathrm{~h}$ cell incubation with liposomes was measured with $o$-phtahalaldehyde as described previously [35]. The glutathione level was normalized to protein content determined with the Lowry method.

\section{Measurement of antioxidant capacity of cell lysates with ABTS cation radical}

Cell lysates obtained after $1 \mathrm{~h}$ cell incubation were used for measurement of antioxidant capacity (AC) by the ABTS cation radical decolorization assay as described previously [35]. The results obtained were standardized to Trolox ${ }^{\circledR}$ and normalized to protein content.

\section{Measurement of cell lysates antioxidant capacity against $\mathrm{HOCl}$}

For the estimation of the influence of phosphatidylcholine and chlorohydrins on the antioxidant capacity of cell lysates against $\mathrm{HOCl}$ the Pyrogallol Red based competitive assay was employed [36]. In brief, different volumes of cell lysates (prepared in three cycles of washing with PBS and centrifugation followed by cell lysis by freezing) were mixed on 96well plate with $5 \mu \mathrm{M}$ Pyrogallol Red solution in $100 \mathrm{mM}$ phosphate buffer $(\mathrm{pH}=7.4)$. Addition of $\mathrm{HOCl}(50 \mu \mathrm{M})$ was followed by immediate and vigorous shaking. After $5 \mathrm{~min}$ the absorbance was read at $540 \mathrm{~nm}$ against a reagent blank. The volume providing $50 \%$ inhibition of Pyrogallol Red oxidation was standardized with respect to ascorbic acid and normalized to the protein content. 


\section{Determination of p38 kinase phosphorylation}

The index of p38 kinase phosphorylation was determined using an ELISA kit (Cell-Based) that allows for simultaneous estimation of total p38 protein level as well as the level of its phosphorylated form. The determination of p38 and p-p38 was carried out according to the instructions provided by the manufacturer after $1.5 \mathrm{~h}$ incubation of cells with liposomes.

\section{Statistical analysis}

The values on the graphs are mean \pm SEM. 3-factor analysis of variance (ANOVA) was performed using the package STATISTICA to determine which factors (lipid chlorination (non-Chloro vs Chloro), fatty acyl composition of the lipids (Lipids), and treatment concentration (Conc) affect the data. The detailed outcome of statistical analysis and interactions between the factors is included in Supplementary Tables, where the notation "Chloro*Lipid*Concentration" relates to the factors above and is used to indicate the interaction of 2 or more factors. For example, "P<0.05 Non-chloro vs Chloro*Lipid*Concentration" indicates that there was a significant difference between the non-chlorinated and chlorinated lipids, and the effect of the chlorination was dependent both on lipid type and the concentration.

\section{Results}

\section{Cytotoxicity of HOCl-oxidized phospahatidylcholines}

Phosphatidylcholines and their modified forms were both found to be cytotoxic towards immortalized human umbilical vein endothelial cells employed in this study, although the toxicity was significantly greater with chlorinated compared to unmodified lipids. Our analysis of HOCl-oxidized phospholipids with MS/MS and ${ }^{1} \mathrm{H}-\mathrm{NMR}$ further demonstrated the prevailing abundance of phospholipid chlorohydrins among the products of the reaction between $\mathrm{HOCl}$ and phosphatidylcholines. ${ }^{1} \mathrm{H}-\mathrm{NMR}$ spectra demonstrate the loss of vinyl protons $(\mathrm{CH}=\mathrm{CH})$, allylic protons $\left(\mathrm{CH}_{2} \mathrm{C}=\right)$ and bis-allylic protons $\left(=\mathrm{CCH}_{2} \mathrm{C}=\right)$ in fatty acid chains of the phospholipids studied, suggesting complete conversion of parent lipids to $\mathrm{HOCl}$ modified products (Supplementary Fig. 1). Furthermore, MS/MS analysis revealed neutral loss of $\mathrm{H}^{35} \mathrm{Cl}$ and $\mathrm{H}^{37} \mathrm{Cl}$ (typical for chlorohydrins [37, 38]) and the presence of chlorohydrin dehydration products, while only small amounts of lysolipids were detected (Supplementary Fig. 2 and 3).

Figure 1 shows the effect of liposomes on HUVEC-ST cell number as a percentage of the untreated cells, analysed by the DNA content. It can be seen that all factors investigated (i.e. the unsaturated fatty acyl chains in the phosphatidylcholines, their conversion into 
chlorohydrins, and the concentration administrated to cell culture) significantly affected toxicity of lipids ( $\mathrm{p}<0.001$ for all factors). The adverse effects of phosphatidylcholine liposomes in the culture increased in the sequence as follow: SOPC $<$ SLPC $<$ SAPC, although liposomes made of unmodified phosphatidylcholines revealed similar rate and intensity of incorporation into cells (Supplementary Fig. 4). Their conversion into chlorinated products enhanced significantly cytotoxicity of these compounds, leading to a dramatic reduction in cell number after $24 \mathrm{~h}$ incubation with SAPC-HOCl liposomes, but only fusion of SLPC$\mathrm{HOCl}$ and SAPC-HOCl liposomes with HUVEC-ST cells was augmented.

\section{Phosphatidylcholine-HOCl oxidation products demonstrate pro-apoptotic activity}

The extent of apoptosis in the cells was determined by cell staining with annexin $\mathrm{V}$ and propidium iodide, followed by analysis of cell fluorescence with flow cytometry (Fig. 1B and 1C). Living cells (lower left corner marked with L on PE/FITC dot plots in Fig. 1B), necrotic cells (upper left corner, N) and apoptotic cells (the sum of early - EA and late - LA apoptotic cells located in lower right and upper right corners, respectively) were counted and presented as bars in Fig. 1C. It was found that the effects of lipids conversion into chlorohydrins on the extent of apoptosis and loss of cell viability depended on the lipid type and concentration used ( $\mathrm{p}<0.001$ for Non-chloro vs Chloro*Lipid*Concentration) and all these factors influenced cell commitment to apoptosis. Panel 1B demonstrates the increase in the number of annexin $\mathrm{V}$ positive cells accompanying cell treatment with SAPC and SAPC-HOCl. In contrast to programmed cell death, enhancement of cell necrosis resulted from lipids treatment with $\mathrm{HOCl}$ and from the increase in the concentration used $(\mathrm{p}<0.05$ for Non-chloro vs Chloro and $\mathrm{p}<0.001$ for Conc), but irrespectively of lipid type.

The mitochondrial membrane potential was analyzed using the dye JC-1, and this demonstrated dissipation of the mitochondrial electrochemical potential gradient after $6 \mathrm{~h}$ incubation of HUVEC-ST cells with liposomes made of phosphatidylcholine (Fig 1D). At higher doses all the chlorohydrins used caused an increase in the green to red fluorescence ratio of JC-1. The intensity of the effects observed depended on the lipid type and its concentration, and was enhanced by addition of $\mathrm{HOCl}$ molecule(s) to fatty acid chains ( $\mathrm{p}<0.01$ for all considered factors). Moreover, the differences between native lipids and HOCl-modified increased in a concentration-dependent manner $(\mathrm{p}<0.05$ for Non-chloro vs Chloro*Conc). A slight drop in mitochondrial potential was also observed in cells incubated with liposomes made of unmodified phosphatidylcholines, but only at the highest doses of SAPC and SLPC. 
Cell double staining with Hoechst 33342 additionally confirmed the contribution of apoptosis to the reduction of cell number observed on the basis of the DNA staining after $6 \mathrm{~h}$ cell incubation with liposomes. The course of programmed cell death was accompanied by morphological changes of cell nucleus typical for the course of apoptosis: condensation of chromatin and formation of apoptotic bodies in HUVEC-ST cells (Fig 1E). HUVEC-ST cells exposed to $100 \mu \mathrm{M}$ SAPC-HOCl for $6 \mathrm{~h}$ revealed both early and late apoptotic morphology.

\section{Caspase-3 and -7 contribute in the course of HOCl-oxidized phosphatidylcholine-} triggered apoptosis

To obtain further evidence for the occurrence of apoptosis, experiments to measure the level of active forms of caspase-3 and caspase-7 with specific antibodies were carried out, and demonstrated significant activation of both proteases as a consequence of cell treatment with native and phospholipid-HOCl oxidation products (Fig. 2A and 2B). The increase in green fluorescence, which corresponded to the level of active caspase-3, as a consequence of lipid treatment with $\mathrm{HOCl}$ depended also on the lipid type and concentration $(\mathrm{p}<0.05$ for Nonchloro vs Chloro*Lipid*Conc). Similarly to the results presented above, SLPC and SAPC at higher doses were able to increase the intracellular concentration of caspase-3, but the level of this enzyme was lower when compared to cells treated with the corresponding HOCl-treated lipid ( $\mathrm{p}<0.001$ for Non-chloro vs Chloro). Similarly, activation of caspase-7 was enhanced in response to lipid oxidation with $\mathrm{HOCl}$ and the increase in concentration of lipids, but also lipid composition affected caspase-7 processing $(\mathrm{p}<0.001$ for Non-chloro vs Chloro, Conc and Lipid).

The use of caspase-3/-7 inhibitor Ac-DEVD-CHO at the final concentration of $5 \mu \mathrm{M}$ effectively inhibited apoptosis initiated by parent and modified phosphatidylcholine liposome in HUVEC-ST cells, as determined using flow cytometry after cell staining with annexin V and propidium iodide (Fig. 2C), indicating the crucial role of these executioner proteases in the cells studied.

\section{Phosphatidylcholine modified by $\mathrm{HOCl}$ affects cell cycle progression}

HOCl-oxidized phosphatidylcholines at the concentration of $50 \mu \mathrm{M}$ affected division of HUVEC-ST cells (Fig. 3). Analysis of the cell cycle demonstrated a statistically significant increase in the number of cells in $\mathrm{G}_{0} / \mathrm{G}_{1}$ phase after $24 \mathrm{~h}$ cell exposure to all chlorinated lipids used in the study. Partial cell arrest in the $\mathrm{G}_{0} / \mathrm{G}_{1}$ phase was followed by the reduction of cell populations in $S$ and $\mathrm{G}_{2} / \mathrm{M}$ phase. As in the experiments described above, the extent of the growth inhibition was strongly dependent on the type of lipid analyzed, concentration used and lipid treatment with $\mathrm{HOCl}(\mathrm{p}<0.05$ for all). The above-mentioned factors influenced cell 
distribution in $\mathrm{G}_{0} / \mathrm{G}_{1}, \mathrm{~S}$ and $\mathrm{G}_{2} / \mathrm{M}$ phase and were dependent on each other ( $\mathrm{p}<0.05$ for Nonchloro vs Chloro*Lipids*Conc in all cell cycle phases).

\section{Redox imbalance and activation of p38 kinase as consequences of HOCl-oxidized phosphatidylcholine action on HUVEC-ST cells}

An increased level of reactive oxygen species accompanied by the drop of glutathione content and antioxidant capacity was found after $1 \mathrm{~h}$ HUVEC-ST cell incubation with liposomes made of phospholipid-HOCl oxidation products (Fig. 4). Augmented ROS production estimated with dihydrorhodamine 123 was observed as a consequence of lipid conversion into HOCl-oxidized products, and differed significantly between concentrations and composition of lipids ( $\mathrm{p}<0.001$ for all factors) (Fig. 4A). Similar pattern of changes was also found for the oxidation of MitoSOX Red probe, which undergoes oxidation upon reaction with superoxide anion released by mitochondria (Fig. 4B); therefore mitochondria can be considered as a significant contributor to ROS generation observed upon cell treatment with HOCl-modified lipids. ROS release from mitochondria was significantly affected by modification of parent lipids with $\mathrm{HOCl}$ as well as by lipid type and concentrations used in our study $(\mathrm{p}<0.001$ for all factors separately and for Non-chloro vs Chloro*Lipid*Conc). All these factors influenced also intracellular concentration of glutathione, antioxidant capacity of cell lysates and phosphorylation of p38 kinase. The first of these parameters decreased most dramatically after $1 \mathrm{~h}$ incubation of cells with SAPC-HOCl (to $\sim 39 \%$ for $100 \mu \mathrm{M} \mathrm{SAPC-HOCl,} \mathrm{when}$ compared to untreated control) (Fig. 4E). Also unmodified phosphatidylcholines caused reduction in the GSH content of HUVEC-ST cells, but the extent of changes observed was smaller than in cells treated with HOCl-modified form of lipids $(\mathrm{p}<0.001$ for Non-chloro vs Chloro). The lysates of cells incubated for $1 \mathrm{~h}$ with HOCl-modified lipids, but also with their native forms, demonstrated reduced antioxidant capacity (Fig. 4C and 4D). Cell treatment with the above-mentioned compounds decreased significantly the ABTS cation radical scavenging ability of cell lysates, as well as the ability to protect Pyrogallol Red against $\mathrm{HOCl}$-induced oxidation in a lipid, concentration and chlorination-dependent manner.

To investigate the possible involvement of $\mathrm{HOCl}$ oxidized phospholipids on cellular signaling, we estimated the phosphorylation of p38 kinase, as this is a known redox sensitive kinase and contributes to a signaling process leading to apoptosis. A $1.5 \mathrm{~h}$ cell incubation with modified phosphatidylcholines was found to cause activation of p38 kinase (Fig. 4F). An increased index of phosphorylation (p-p38/p38) was found in HUVEC-ST cells exposed to both unmodified and $\mathrm{HOCl}$-modified phosphatidylcholines, but the enhancement of effects resulting from lipid conversion into the HOCl-modified form depended on the lipid structure 
and concentration administrated to cell culture $(\mathrm{p}<0.001$ for all factors separately and for Non-chloro vs Chloro*Lipid*Conc).

\section{Discussion}

A possible role for $\mathrm{HOCl}$-modified lipids in pathogenesis of atherosclerosis has been suggested by the demonstration that they occur in atherosclerotic lesions, cause increased leukocyte-endothelial adhesion in arterial segments, and may also contribute to formation of the necrotic core of atherosclerotic lesions owing to their toxicity [16, 39, 40]. However, questions about the mechanism of toxicity to cells remain. Here, we confirmed the toxicity of liposomes made of phospahtidylcholine- $\mathrm{HOCl}$ oxidation products to HUVEC-ST cells (immortalized endothelial cells), demonstrating that cell treatment with modified lipids for 24 $\mathrm{h}$ reduced cell number compared to untreated controls by the induction of programmed cell death and growth arrest. Using 3-factor Anova we also demonstrate that lipid-oxidation dependent enhancement in cell commitment to apoptosis as well in accumulation of cells in $\mathrm{G}_{0} / \mathrm{G}_{1}$ phase is affected by lipid type and concentration used (all these factors influenced each other in both experiments, $\mathrm{p}<0.05$ for Non-chloro vs Chloro*Lipid*Conc). As we showed in previously published papers $[18,37,38]$, and confirmed in the present study, hypochlorous acid attacked double bonds leading to addition of $-\mathrm{Cl}$ and $-\mathrm{OH}$ to two adjacent carbons in fatty acid chains and formation of the corresponding chlorohydrins. Because the other products of phosphatidylcholines oxidation with $\mathrm{HOCl}$ and lysolipids occurred at much lower concentration, chlorohydrins are considered as mediators of $\mathrm{HOCl}$ action in cellular systems.

Previously, there had been conflicting reports on the mechanisms of cell death brought about by lipid or fatty acid chlorohydrins [19, 21]. Although Vissers et al. used the same method as in our study (annexin V/propidium iodide double-staining), they did not observe any increase in the number of early apoptotic cells (annexin $\mathrm{V}$ positive, propidium iodide negative) after HUVEC treatment with $100 \mu \mathrm{M}$ oleic acid chlorohydrin for $90 \mathrm{~min}$. Moreover, they did not report the formation of double-positive population of cells as we did, and most of the cells showed only red fluorescence, leading to the conclusion that there was direct necrosis, accompanied by cell lysis. A possible explanation could be different approaches to identification of apoptotic cells after annexin V/propidium iodide staining. In this study, we distinguished between apoptotic (all annexin V positive cells) and necrotic (propidium iodide positive/annexin $\mathrm{V}$ negative cells) populations, while Vissers et al. considered all red fluorescent cells (also double-stained) as necrotic. Even using their criteria for apoptosis we 
still obtain a statistically significant increase in the number of early apoptotic cells $(4.97 \pm$ $0.67 \%, 8.35 \pm 1.37 \%$, and $13.65 \pm 3.85 \%$ for SOPC-HOCl, SOPC-HOCl and SAPC-HOCl, respectively). The occurrence of necrosis according to Vissers et al. was attributed to disruption of the plasma membrane owing to incorporation of fatty acid chlorohydrins, which have a more polar and bulky nature than native phospholipids. It has also been shown that conversion of unsaturated phospholipids into chlorohydrins results in a stronger incorporation of liposomes into red blood cells, an increase of lipid order, decrease of permeability of the lipid bilayer in liposomes [18]. A later study reported that SOPC chlorohydrin induced apoptosis of U937 monocytic cells with the activation of caspase-3 [21]. In the current study, increase in the intensity of programmed cell death in response to phosphatidylcholine conversion into HOCl-modified analogs was evident in the HUVEC-ST cells after $6 \mathrm{~h}$ incubation with lipids; they showed classical, frequently described features of apoptosis, including dissipation of the mitochondrial membrane potential, externalization of phosphatidylserine, activation of caspase-3 and caspase-7, chromatin condensation and formation of apoptotic bodies. Notably, all these pro-apoptotic and pro-necrotic effects were found after cell incubation with pathophysiological concentrations of $\mathrm{HOCl}$-oxidized phospholipids. The highest concentration used in our study did not exceed $100 \mu \mathrm{M}$ (significant cellular disorders were caused by far lower doses, around $10 \mu \mathrm{M}$ for SAPC$\mathrm{HOCl}$ ), while acute pancreatitis triggered in a mouse model was accompanied by generation of chlorohydrin reaching a concentration of $250 \mu \mathrm{M}$ in ascitic fluid [17].

The liposomes made of SLPC-HOCl and SAPC-HOCl were demonstrated to incorporate to a far higher extent than parent phosphatidylcholines, while SOPC, SLPC, SAPC and SOPC$\mathrm{HOCl}$ revealed a similar rate and intensity of fusion with HUVEC cells, but the toxicity differed significantly between all lipid types, as well as between HOCl-treated and untreated phosphatidylcholines. Thus, the biophysical parameters of liposome bilayer seem to have limited impact on cell apoptosis and the effects of fatty acid chlorohydrins may differ from phospholipid chlorohydrins. In the model we studied, increased cytotoxicity resulting from phosphatidylcholine oxidation with $\mathrm{HOCl}$ was also significantly influenced by the type of lipid (Fig. 1A, p<0.001 for Non-chloro vs Chloro*Lipid). Therefore, the observed effects seem to depend on the number of $\mathrm{HOCl}$ molecules added to phosphatidylcholine fatty acid chains. It is also important to bear in mind that SAPC-HOCl, which had the highest activity, also contained the highest proportion of lysolipids (up to $\sim 10 \%$ ). Cytotoxicity of lysolipids has been reported previously, although it was also found that they did not affect membrane asymmetry and could not contribute to observed externalization of phosphatidylserine [41]. In 
terms of cell membrane localization of HOCl-modified lipids, the structure of the lipid molecule is likely to be of crucial importance as it may affect the local membrane environment. As we demonstrated previously, an increase in level of chlorination was accompanied by an increase in liposome membrane rigidity and erythrocyte lysis [18]. Such alterations in cellular membrane structure or intracellular membranes may impair or trigger signaling pathways and intracellular events, e.g. apoptosis.

The key role of caspase- 3 and caspase- 7 in the course of apoptosis induced by phosphatidylcholines- $\mathrm{HOCl}$ oxidation products was indicated by the observation that preincubation of the cells with a caspase-3/-7 inhibitor (Ac-DEVD-CHO) effectively protected them against programmed death. We found a concentration, lipid and chlorination-dependent increase in cell fluorescence corresponding to the intracellular concentration of the active caspase- 3 and caspase- 7 after $6 \mathrm{~h}$ of incubation, reaching the highest value for $100 \mu \mathrm{M} \mathrm{SAPC-}$ $\mathrm{HOCl}$ treated cells. This initially does not appear to agree with the hypothesis of concentration-dependent mode of cell death suggested previously [21], whereby lower doses of chlorohydrins were thought to induce apoptosis and higher doses caused necrosis. However, in the study by Dever et al., cells were treated with HOCl-modified SOPC and SAPC for $24 \mathrm{hrs,}$ which may have allowed the cells to progress further towards a secondary necrosis, and could account for the effects observed [21].

After $6 \mathrm{~h}$ incubation we observed augmented decline in the mitochondrial membrane potential in a consequence of cell treatment with HOCl-modified phosphatidylcholines when compared to parent lipids, which was also dependent on the concentration and type of lipid. It is difficult to speculate on the mechanism underlying the loss of mitochondria function as sufficient and convincing data have not been published yet, but the possibility of oxidized lipid interaction and incorporation into mitochondria membrane should be taken into consideration, as a study on the fluorescently labeled electrophilic lipid $15 \mathrm{~d}-\mathrm{PGJ}_{2}$ showed strong colocalization with mitochondria and enhanced generation of reactive oxygen species from these organelles in endothelial cells [42]. Furthermore, the oxidized phospholipid PazePC was documented to increase membrane-association of pro-apoptotic Bax protein, which triggers outer membrane permeabilization [43]. The HOCl-modified phosphatidylcholines studied here led to a relatively rapid increase in ROS generation by mitochondria (observed after $1 \mathrm{~h}$ cell treatment with liposomes), followed by a decline in mitochondria membrane potential comparied to the corresponding native lipids. Therefore, the possible oxidized lipid cross-talk with mitochondria may involve many mechanisms. The dissipation of the mitochondrial membrane potential is usually followed by the release of pro-apoptotic factors, occurring thus as an early 
event of apoptosis leading to activation of effector caspases [44]. Also in case of $\mathrm{HOCl}-$ modified phosphatidylcholines, the loss of mitochondria membrane potential was followed by activation of caspase- 3 and caspase-7 and externalization of phosphatidylserine. Bearing in mind the rapid production of reactive oxygen species by mitochondria upon treatment with HOCl-PC, these organelles seem to play a key role in apoptosis induction in our cellular model, although the external, cell membrane-associated signaling routes cannot be excluded. These findings suggest that phospholipid- $\mathrm{HOCl}$ oxidation products may act also as signaling molecules affecting cell regulatory pathways. Our experiments further demonstrated activation of p38 kinase as a result of relatively short exposure of HUVEC-ST cells to HOClmodified phosphatidylcholine, significantly stronger than that with non-oxidized lipids. This enzyme, phosphorylated under different types of stress e.g. excessive ROS production, was documented to undergo activation also in cells subjected to the action of LDL and oxLDL $[45,46]$. When phosphorylated, p38 kinase may contribute to e.g. apoptosis induction, inhibition of cell proliferation, and pro-inflamatory cytokine release.

Some data have indicated the possibility of p53-dependent apoptosis induced by oxidatively modified LDL due to the release of reactive oxygen species (ROS) by disrupted mitochondria [6]. Thus, the mechanism underlying the triggering of apoptosis in cells by HOCl-modified phosphatidylcholines may be similar to that found for oxLDL. Our results confirmed the enhanced indirect pro-oxidative properties of phosphatidylcholines upon their treatment with $\mathrm{HOCl}$ in the culture of HUVEC-ST cells. When added to cell culture, these compounds caused a decrease in GSH content, accompanied by reduced antioxidant capacity of cell extracts and elevated ROS level, which seem to result mostly from impaired mitochondria, as shown with the MitoSOX Red fluorescent probe. Moreover, these compounds have not yet been found to be reactive or oxidize/chlorinate other biological molecules, which limits the possibility of their direct action on the activity of ROS-producing enzymes. Although some data in the literature point at possible covalent as well as non-covalent interaction of lipids with proteins [47, 48], these findings concern mostly interactions between lipid aldehydes with nucleophilic centers and $\alpha-\beta$ unsaturated carbonyls with thiolate groups.

OxLDL has been found to inhibit the proliferation of endothelial cells, in contrast to its growth-promoting effects on smooth muscle cells (SMCs) and monocyte-macrophages, although the mechanism involved was not elucidated [49]. Here, we have shown that in addition to causing apoptosis, phosphatidylcholines modified by $\mathrm{HOCl}$ were found to affect the proliferation ability of cultured cells, arresting them in $G_{0} / G_{1}$ phase. Thus our study has shown that phospholipid-HOCl oxidized products have effects that could account for the 
oxLDL-induced apoptosis and inhibition of proliferation observed previously, but further experiments are necessary to confirm their role.

In summary, our data clearly indicate that HOCl-oxidized phosphatidylcholines at pathophysiologically relevant concentrations have complex cellular effects, significantly stronger than corresponding non-modified lipids. All methods utilized in this study support the conclusion that our modified lipids trigger apoptosis in immortalized endothelial cells in addition to other cellular disturbances such as redox imbalance and proliferation impairment in a lipid and concentration-dependent manner. Therefore, the pro-apoptotic properties of these molecules may contribute to the induction or/and progression of atherosclerosis or other inflammatory conditions where HOCl-modified lipids are likely to occur.

\section{References}

[1] T. Stefanec, Chest 117 (2000) 841-854.

[2] X. Bai, X. Wang, Q. Xu, Vascul Pharmacol 52 (2010) 224-229.

[3] P. Cullen, J. Rauterberg, S. Lorkowski, Handb Exp Pharmacol (2005) 3-70.

[4] S. Dimmeler, C. Hermann, A.M. Zeiher, Eur Cytokine Netw 9 (1998) 697-698.

[5] S. Liu, H. Shen, M. Xu, O. Liu, L. Zhao, Z. Guo, J. Du, Am J Physiol Endocrinol Metab 299 (2010) E351-363.

[6] J. Cheng, R. Cui, C.H. Chen, J. Du, Endocrinology 148 (2007) 2085-2094.

[7] F. Robbesyn, R. Salvayre, A. Negre-Salvayre, Free Radic Res 38 (2004) 541-551.

[8] H. Itabe, Clin Rev Allergy Immunol 37 (2009) 4-11.

[9] A. Daugherty, J.L. Dunn, D.L. Rateri, J.W. Heinecke, J Clin Invest 94 (1994) 437-444.

[10] S.L. Hazen, J.W. Heinecke, J Clin Invest 99 (1997) 2075-2081.

[11] P.G. But, V.A. Fomina, R.A. Murav'ev, V.V. Rogovin, Izv Akad Nauk Ser Biol (2003) 261-265.

[12] K.P. Leung, M.B. Goren, Cell Tissue Res 257 (1989) 653-656.

[13] C.C. Winterbourn, Toxicology 181-182 (2002) 223-227.

[14] A.C. Carr, M.C. Vissers, N.M. Domigan, C.C. Winterbourn, Redox Rep 3 (1997) 263271.

[15] A. Jerlich, A.R. Pitt, R.J. Schaur, C.M. Spickett, Free Radic Biol Med 28 (2000) 673682.

[16] M.C. Messner, C.J. Albert, J. McHowat, D.A. Ford, Lipids 43 (2008) 243-249. 
[17] N. Franco-Pons, J. Casas, G. Fabriàs, S. Gea-Sorlí, E. de-Madaria, E. Gelpí, D. Closa, Annals of Surgery 257 (2013) 943-951.

[18] A. Robaszkiewicz, F.H. Greig, A.R. Pitt, C.M. Spickett, G. Bartosz, M. Soszynski, Chem Phys Lipids 163 (2010) 639-647.

[19] M.C. Vissers, A.C. Carr, C.C. Winterbour, Redox Rep 6 (2001) 49-55.

[20] G. Dever, L.J. Stewart, A.R. Pitt, C.M. Spickett, FEBS Lett 540 (2003) 245-250.

[21] G. Dever, C.L. Wainwright, S. Kennedy, C.M. Spickett, Acta Biochim Pol 53 (2006) 761-768.

[22] L. Tentori, M. Vergati, A. Muzi, L. Levati, F. Ruffini, O. Forini, P. Vernole, P.M. Lacal, G. Graziani, Int J Oncol 27 (2005) 525-535.

[23] F. Szoka, F. Olson, T. Heath, W. Vail, E. Mayhew, D. Papahadjopoulos, Biochim Biophys Acta 601 (1980) 559-571.

[24] J.C. Stewart, Anal Biochem 104 (1980) 10-14.

[25] A. Robaszkiewicz, G. Bartosz, M. Soszynski, J Immunol Methods 369 141-145.

[26] K. Solarska-Sciuk, A. Gajewska, J. Skolimowski, K. Mitura, G. Bartosz, Biotechnol Appl Biochem 60 259-265.

[27] A. Robaszkiewicz, G. Bartosz, M. Soszynski, Toxicology 270 (2010) 112-120.

[28] S.T. Smiley, M. Reers, C. Mottola-Hartshorn, M. Lin, A. Chen, T.W. Smith, G.D. Steele, Jr., L.B. Chen, Proc Natl Acad Sci U S A 88 (1991) 3671-3675.

[29] Y. Inai, M. Yabuki, T. Kanno, J. Akiyama, T. Yasuda, K. Utsumi, Cell Struct Funct 22 (1997) 555-563.

[30] I. Vermes, C. Haanen, H. Steffens-Nakken, C. Reutelingsperger, J Immunol Methods 184 (1995) 39-51.

[31] E. Bedner, X. Li, W. Gorczyca, M.R. Melamed, Z. Darzynkiewicz, Cytometry 35 (1999) 181-195.

[32] G. Lizard, S. Fournel, L. Genestier, N. Dhedin, C. Chaput, M. Flacher, M. Mutin, G. Panaye, J.P. Revillard, Cytometry 21 (1995) 275-283.

[33] N.J. Stapper, M. Stuschke, A. Sak, G. Stuben, Int J Cancer 62 (1995) 58-62.

[34] Z. Darzynkiewicz, G. Juan, E. Bedner, Curr Protoc Cell Biol Chapter 8 (2001) Unit 84.

[35] A. Robaszkiewicz, M. Pogorzelska, G. Bartosz, M. Soszynski, Toxicology in vitro 25 (2011) 1328-1334.

[36] A. Robaszkiewicz, G. Bartosz, Biochem Biophys Res Commun 390 (2009) 659-661.

[37] A.R. Pitt, C.M. Spickett, Biochem Soc Trans 36 (2008) 1077-1082.

[38] C.M. Spickett, A. Reis, A.R. Pitt, Free Radic Biol Med 51 (2011) 2133-2149. 
[39] C.M. Spickett, Pharmacol Ther 115 (2007) 400-409.

[40] G.J. Dever, R. Benson, C.L. Wainwright, S. Kennedy, C.M. Spickett, Free Radic Biol Med 44 (2008) 452-463.

[41] M. Traikia, C. Marbeuf-Gueye, E. Hantz, L. Le Moyec, Chem Biol Interact 151 (2005) 83-94.

[42] A. Landar, J.W. Zmijewski, D.A. Dickinson, C. Le Goffe, M.S. Johnson, G.L. Milne, G. Zanoni, G. Vidari, J.D. Morrow, V.M. Darley-Usmar, Am J Physiol Heart Circ Physiol 290 (2006) H1777-1787.

[43] M. Wallgren, M. Lidman, Q.D. Pham, K. Cyprych, G. Grobner, Biochim Biophys Acta 1818 (2012) 2718-2724.

[44] D.R. Green, J.C. Reed, Science 281 (1998) 1309-1312.

[45] C. Giovannini, R. Vari, B. Scazzocchio, M. Sanchez, C. Santangelo, C. Filesi, M. D'Archivio, R. Masella, J Mol Cell Biol 3 (2011) 316-318.

[46] N. Bulat, G. Waeber, C. Widmann, J Lipid Res 50 (2009) 81-89.

[47] J.W. Zmijewski, A. Landar, N. Watanabe, D.A. Dickinson, N. Noguchi, V.M. DarleyUsmar, Biochemical Society transactions 33 (2005) 1385-1389.

[48] C.M. Spickett, Redox Biol 1 (2013) 145-152.

[49] G.M. Chisolm, 3rd, Y. Chai, Free Radic Biol Med 28 (2000) 1697-1707.

\section{Figure legends}

Figure 1. Phosphatidylcholine modified by HOCl triggers apoptosis in cultured HUVEC-ST cells.

(A) The cytotoxicity of liposomes made of native and modified phosphatidylcholines after 24 $\mathrm{h}$ cell incubation was estimated on the basis of the DNA quantity which corresponds to cell number. (B and C) The flow cytometry analysis of cells double stained with annexin $\mathrm{V}$ and propidium iodide was employed for the estimation of pro-apoptotic properties of liposomes added to the growth medium for $6 \mathrm{~h}$. (B) Annexin V positive cells were assumed as apoptotic $(\mathrm{EA}+\mathrm{LA})$, propidium iodide $(\mathrm{PI})$ positive as necrotic $(\mathrm{N})$, while double negative cells as living (L). Dissipation of mitochondrial potential (D) in cells exposed to wide range of $\mathrm{HOCl}-$ modified and intact phospholipids concentration for $6 \mathrm{~h}$ was observed on the basis of cell double staining with JC-1/PI, while the alteration of chromatin structure (E) in cells incubated with SAPC-HOCl for $6 \mathrm{~h}$ after cell staining with Hoechst 33342. Dark cells exhibiting no fluorescence were assumed as living, brightly fluorescent with chromatin condensed as early apoptotic, while cells with chromatin distributed to apoptotic bodies were assumed as late 
apoptotic. Results are presented as mean \pm SEM. ANOVA (3-factor): Significant effects for panel (A): Non-chloro vs Chloro F=352.8 (p<0.001), Lipids F=53.0 (p<0.001), Conc F=99.8 $(\mathrm{p}<0.001)$, Fisher's PLSD = 11.87; for panel (C): LIVING; Non-chloro vs Chloro F=91.9 $(\mathrm{p}<0.001)$, Lipids $\mathrm{F}=34.9$ ( $\mathrm{p}<0.001)$, Conc $\mathrm{F}=171 \quad(\mathrm{p}<0.001)$, Fisher's PLSD = 3.67; significant effects for APOPTOSIS; Non-chloro vs Chloro F=56.2 ( $\mathrm{p}<0.001)$, Lipids F=27.2 ( $\mathrm{p}<0.001)$, Conc $\mathrm{F}=112$ ( $\mathrm{p}<0.001)$, Fisher's PLSD = 3.92; significant effects for NECROSIS; Non-chloro vs Chloro F=4.71 ( $\mathrm{p}<0.05)$, Conc F=16.58 ( $\mathrm{p}<0.001)$, Fisher's PLSD = 2.26; for panel (D): Non-chloro vs Chloro F=30.9 (p<0.001), Lipids F=7.02 ( $p<0.01)$, Conc F=39.3 $(\mathrm{p}<0.001)$, Fisher's PLSD $=0.03$.

Figure 2. HOCl-oxidized phosphatidylcholine-triggered apoptosis proceeds with the involvement of executioner caspases: caspase-3 and caspase-7

The intracellular level of the active form of caspase-3 (A) and caspase-7 (B) in cells exposed to the action of native phospholipids and phospholipid-HOCl oxidation products for $6 \mathrm{~h}$ was evaluated using the combination of immunostaining and flow cytometry. (C) Cell incubation with liposomes $(6 \mathrm{~h})$ was preceded with $1 \mathrm{~h}$ cell treatment with the inhibitor of executioner caspase-3/-7 (Ac-DEVD-CHO). Subsequently, cells were stained and analyzed as showed in Figure 1B. ANOVA (3-factor): Significant effects for panel (A): Non-chloro vs Chloro $\mathrm{F}=45.9$ ( $\mathrm{p}<0.001)$, Lipids F=31.0 ( $<<0.001)$, Conc F=74.1 ( $\mathrm{p}<0.001)$, Fisher's PLSD = 27.8; for panel (B): Non-chloro vs Chloro $F=19.0$ ( $p<0.001)$, Lipids $F=54.6$ ( $p<0.001)$, Conc $\mathrm{F}=98.3(\mathrm{p}<0.001)$, Fisher's PLSD = 15.7

Figure 3. Products of phosphatidylcholines oxidation by $\mathrm{HOCl}$ affect proliferation of HUVEC-ST cells

Cell cycle was examined after $24 \mathrm{~h}$ cell incubation with liposomes made of parent phospholipids and modified by $\mathrm{HOCl}(50 \mu \mathrm{M})$ on the basis of DNA content in single cells. Cells were permeabilized, stained with propidium iodide and analyzed by flow cytometry. Bars on the figure present the mean \pm SEM. ANOVA (3-factor): Significant effects for $G_{0} / G_{1}$ : Non-chloro vs Chloro F=82.9 ( $\mathrm{p}<0.001$ ), Lipids $F=17.5$ ( $\mathrm{p}<0.001$ ), Conc $F=105.4$ ( $\mathrm{p}<0.001$ ), Fisher's PLSD = 4.46; S: Non-chloro vs Chloro F=24.2 ( $<<0.001)$, Lipids $F=6.06(p<0.05)$, Conc F=625.1 $(\mathrm{p}<0.001)$, Fisher's PLSD $=4.78 ; \mathrm{G}_{2} / \mathrm{M}$ : Non-chloro vs Chloro $\mathrm{F}=47.1$ ( $p<0.001)$, Lipids F=7.99 ( $p<0.01)$, Conc F=77.2 ( $p<0.001)$, Fisher's PLSD = 2.48. 


\section{Figure 4. Exposure of HUVEC-ST cells to phosphatidylcholine modified by HOCl}

results in redox imbalance

Generation of reactive oxygen species (A) inside cells subjected to the action of liposomes for $1 \mathrm{~h}$ was studied using dihydrorhodamine 123 staining, while release of superoxide anion from mitochondria (B) with MitoSOX Red. Protection of Pyrogallol Red against HOCl-induced oxidation was measured in cell lysates collected after $1 \mathrm{~h}$ cell incubation with liposomes (C), while antioxidant capacity (AC) was estimated on the basis of ABTS cation radical decolorization (D). Concentration of glutathione (E) was measured spectrofluorometrically after derivatization with $o$-phtalaldehyde. The phophorylation index of p38 kinase was determined using cell based ELISA method in cells incubated for $1.5 \mathrm{~h}$ with chlorohydrins and unmodified lipids (F). Bars on the figure present the mean \pm SEM. ANOVA (3-factor): Significant effects for panel (A): Non-chloro vs Chloro $F=84.4$ ( $p<0.001)$, Lipids $F=18.2$ $(\mathrm{p}<0.001)$, Conc $\mathrm{F}=43.5$ ( $\mathrm{p}<0.001)$, Fisher's PLSD = 10.2; for panel $(\mathbf{B})$ : Non-chloro vs Chloro F=382.3 ( $\mathrm{p}<0.001)$, Lipids F=145.3 ( $\mathrm{p}<0.001)$, Conc F=326.8 ( $\mathrm{p}<0.001)$, Fisher's PLSD = 3.48; for panel $(\mathbf{C})$ : Non-chloro vs Chloro F=6.15 (p<0.05), Lipids F=3.67 ( $<<0.05)$, Conc F=25.2 ( $\mathrm{p}<0.001)$, Fisher's PLSD = 12.6; for panel $(\mathbf{D})$ : Non-chloro vs Chloro F=5.41 ( $\mathrm{p}<0.05$ ), Lipids F=11.7 ( $\mathrm{p}<0.01)$, Conc F=93.7 ( $\mathrm{p}<0.001)$, Fisher's PLSD = 3.54; for panel (E): Non-chloro vs Chloro $F=109.9$ ( $\mathrm{p}<0.001)$, Lipids $F=44.5 \quad(\mathrm{p}<0.001)$, Conc $\mathrm{F}=63.9$ $(\mathrm{p}<0.001)$, Fisher's PLSD = 1.00; for panel $(\mathbf{F})$ : Non-chloro vs Chloro F=22.7 $(\mathrm{p}<0.001)$, Lipids F=28.3 ( $\mathrm{p}<0.001)$, Conc F=51.3 ( $\mathrm{p}<0.001)$, Fisher's PLSD = 0.07. 

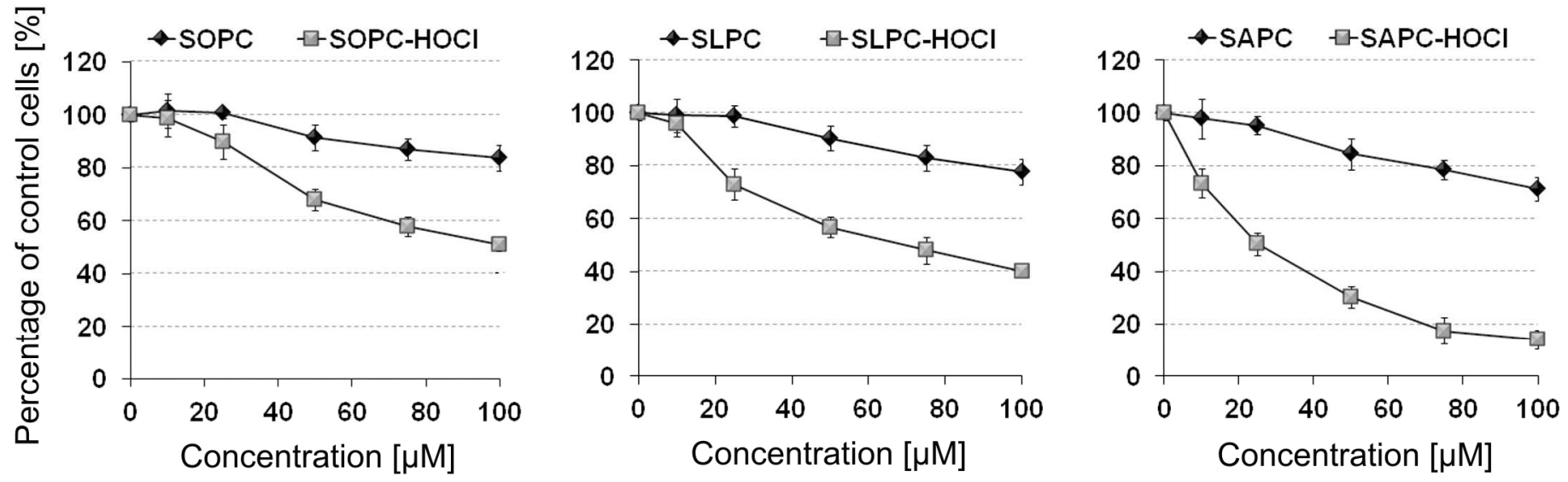

B
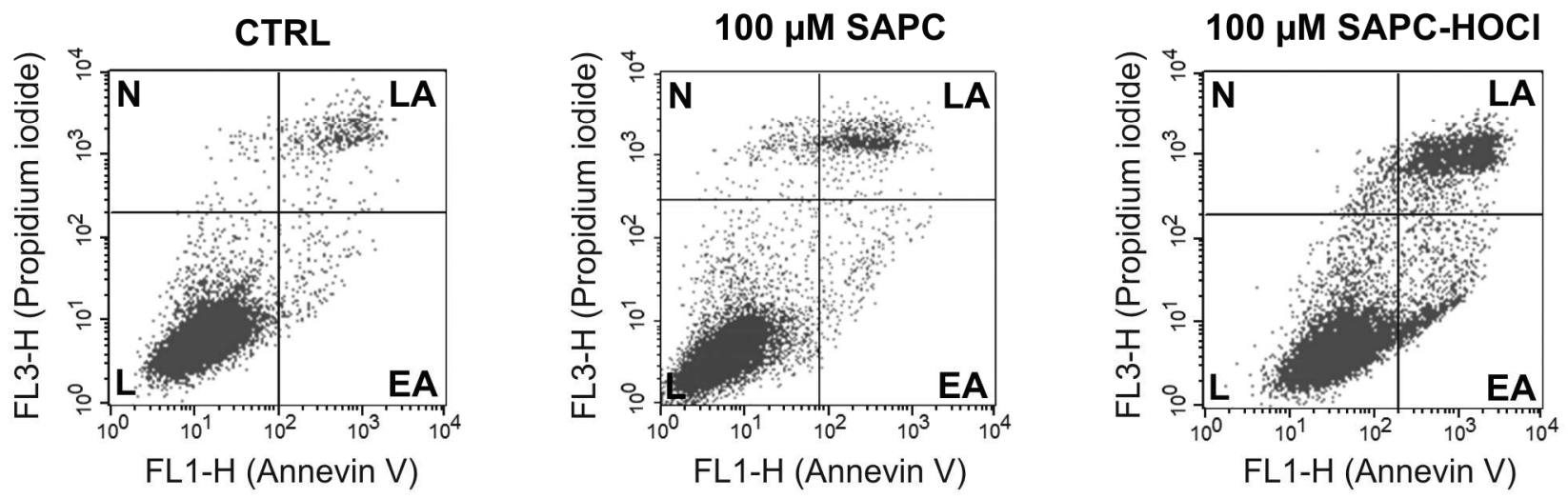

C FL1-H (Annevin V)

— Phospholipid

Phospholipid-HOCl
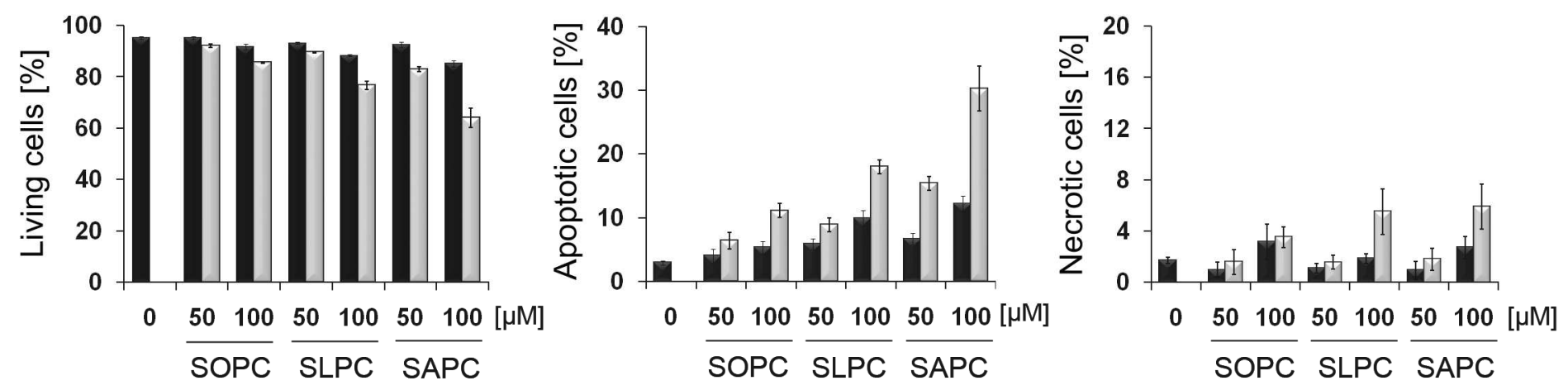

D
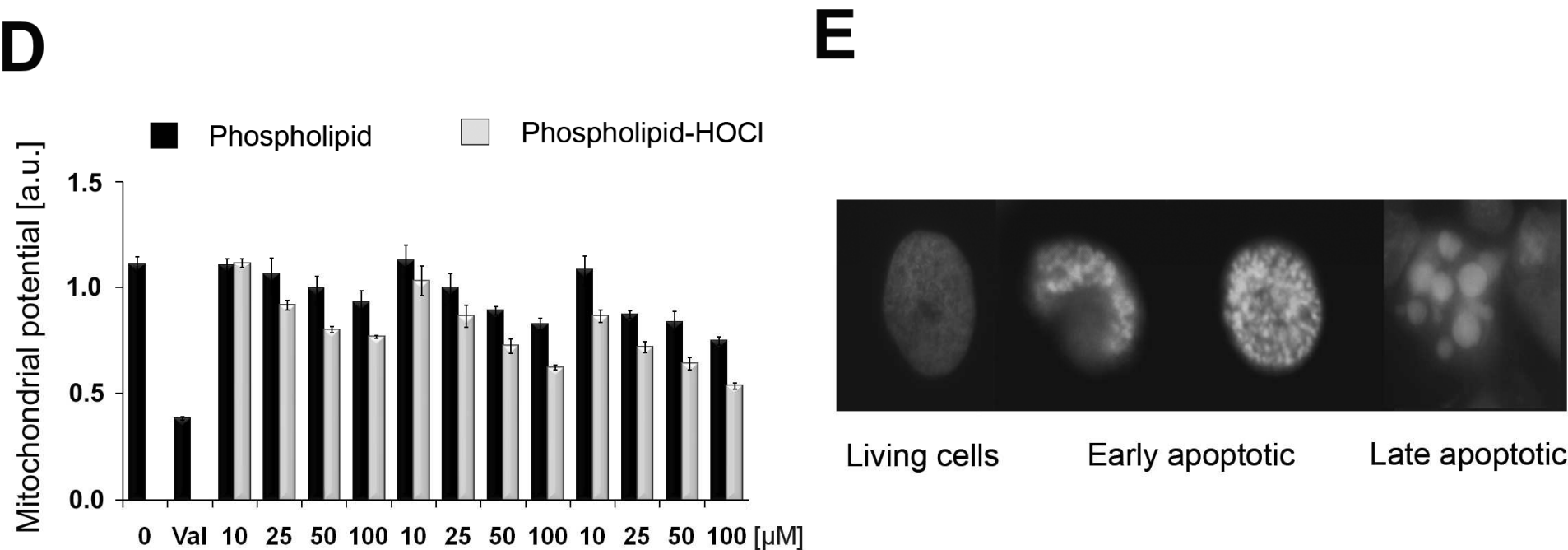

Living cells

Early apoptotic

Late apoptotic

$$
\text { SLPC SAPC }
$$


Figure 2

A

— Phospholipid

Phospholipid-HOCl

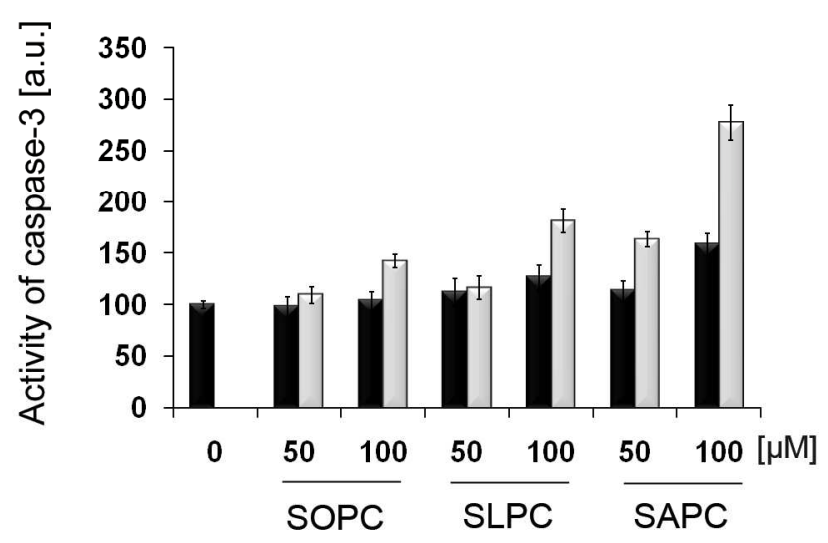

\section{C}

- Phospholipid

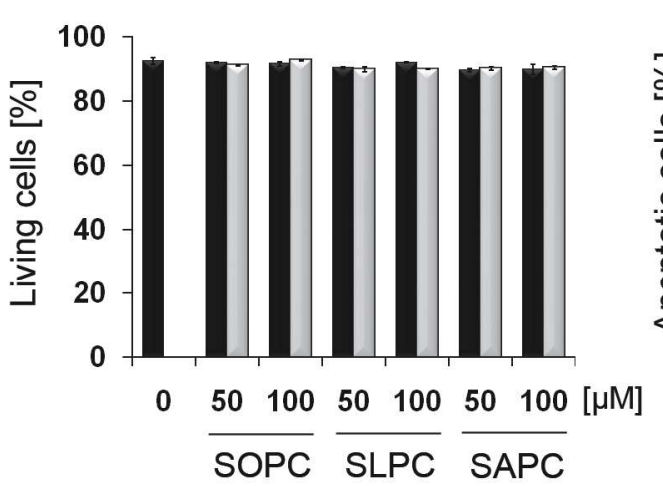

Phospholipid-HOCl
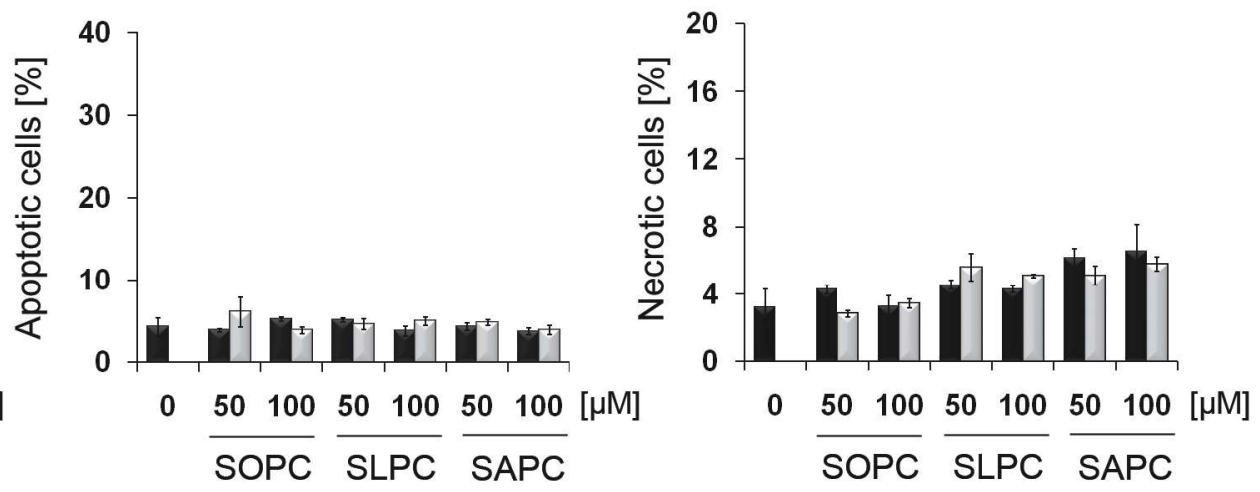
Figure 3
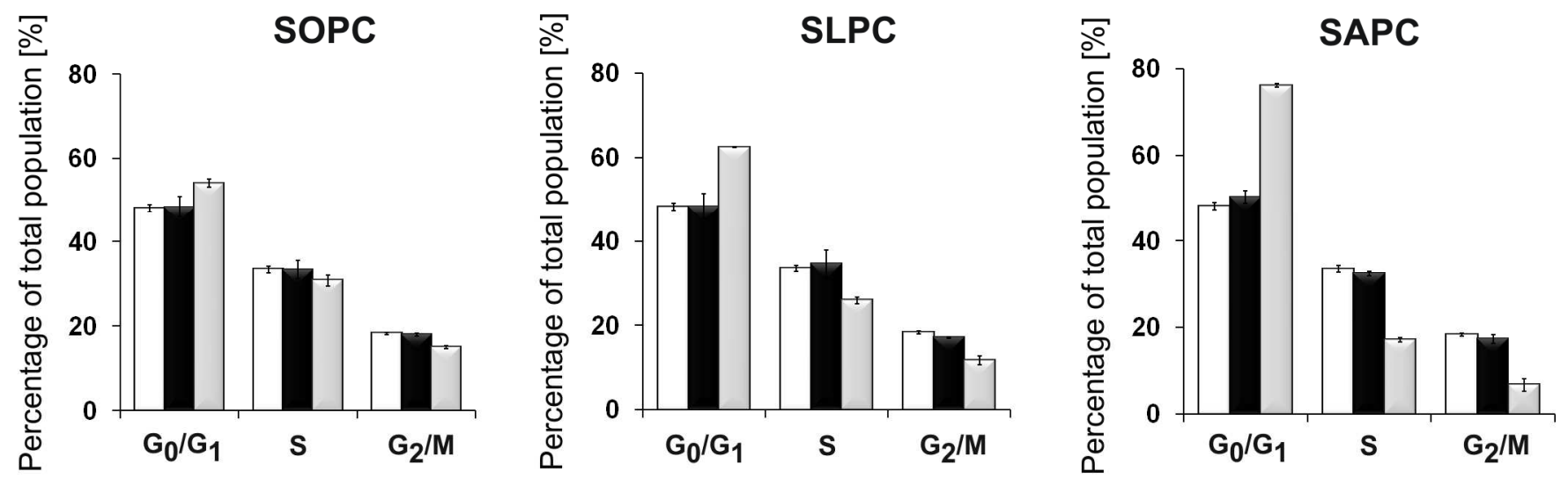
A

Phospholipid

Phospholipid-HOCl
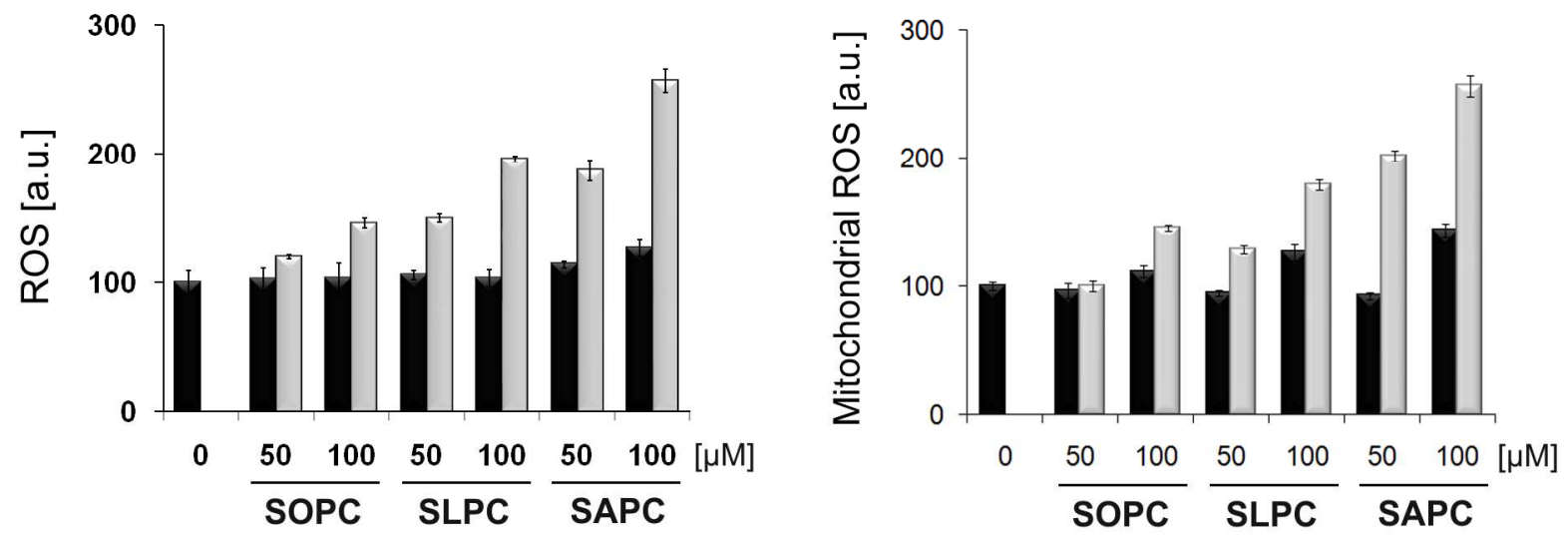

C

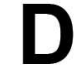

- Phospholipid $\quad \square$ Phospholipid-HOCl
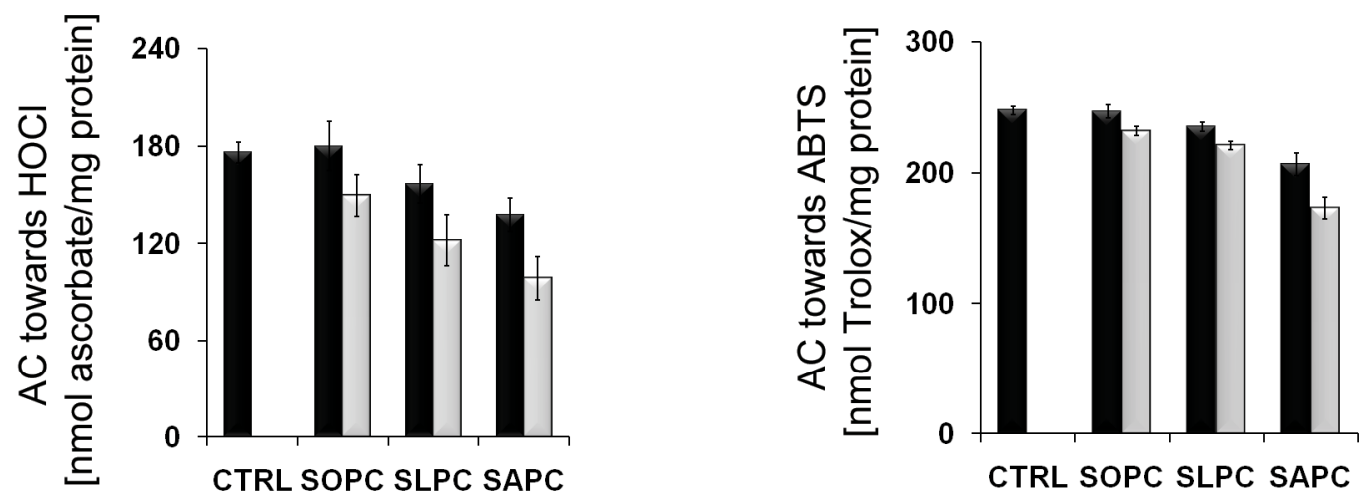

EE

E
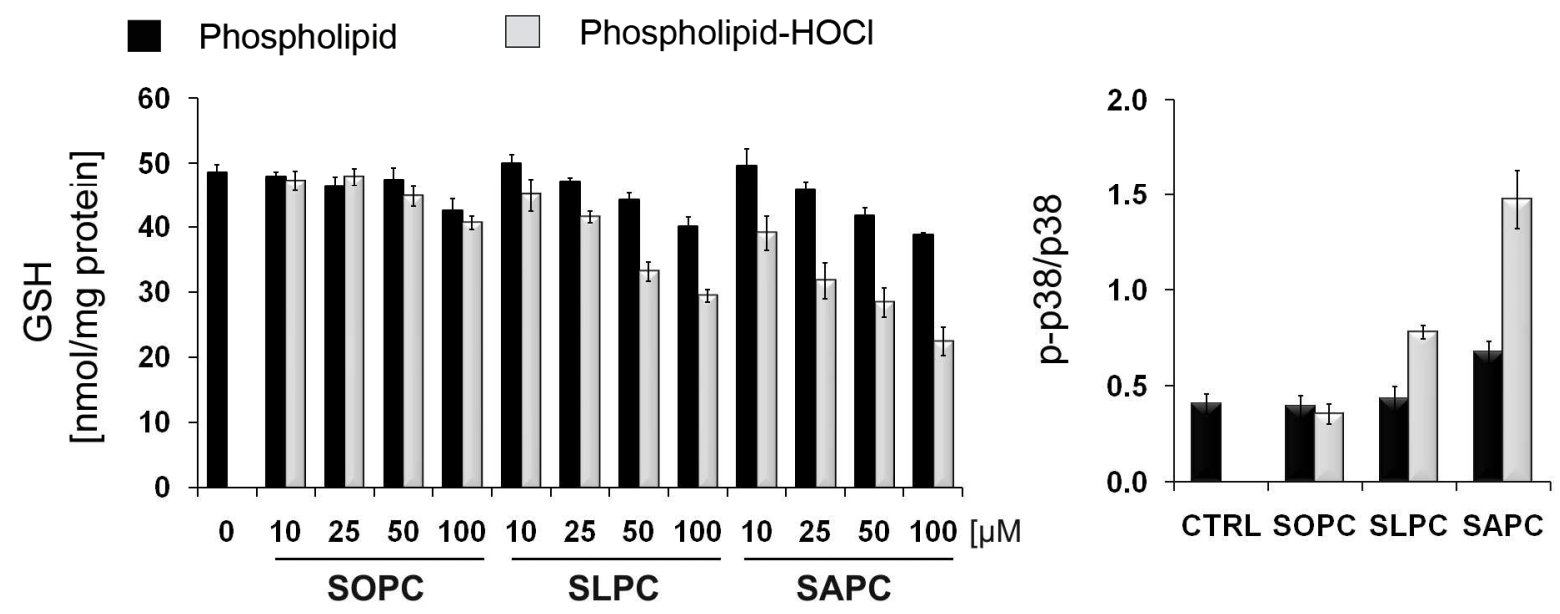

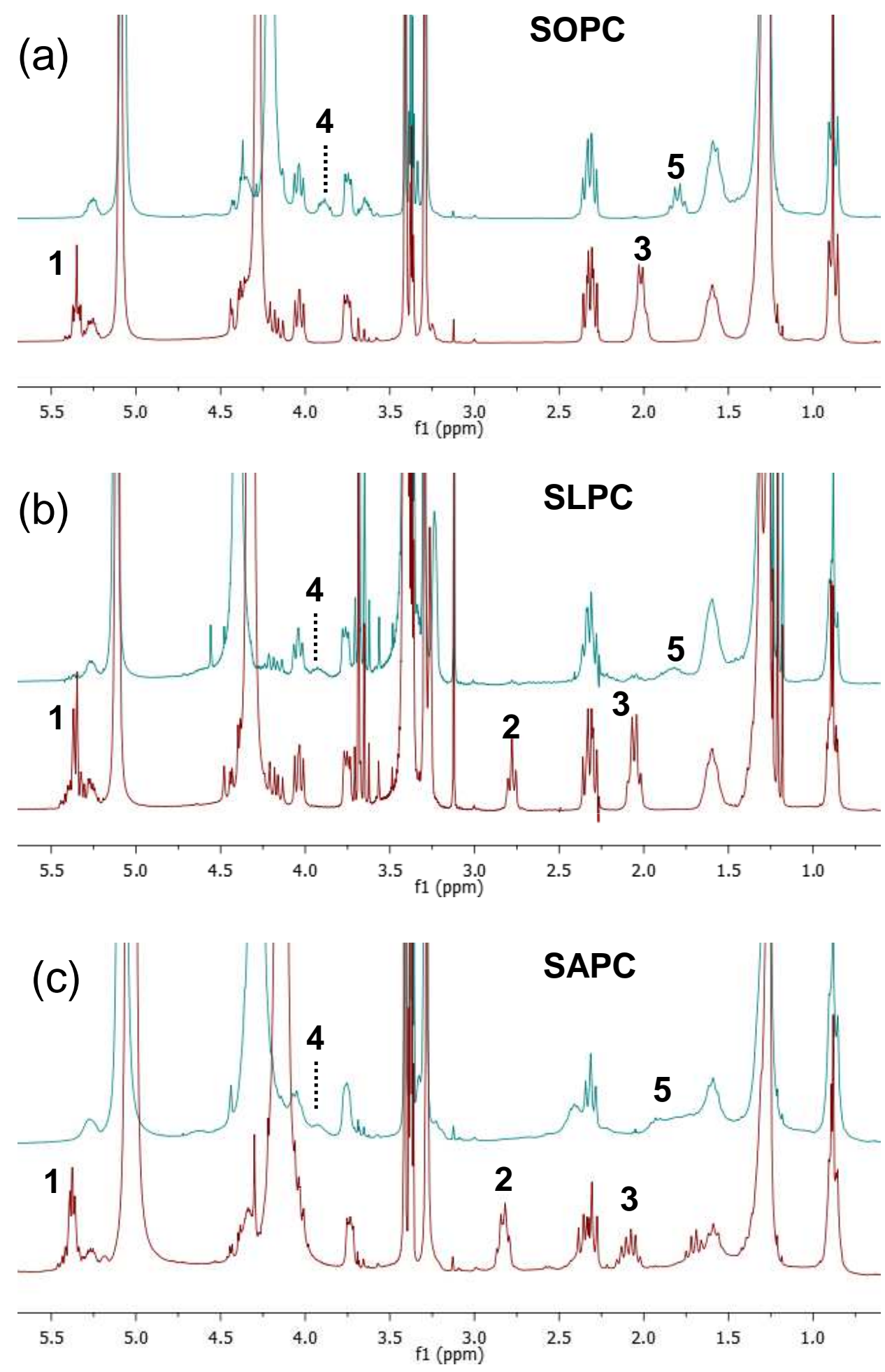

Supporting Figure 1. ${ }^{1} \mathrm{H}-\mathrm{NMR}$ spectra showing the formation of chlorohydrins from SOPC (a), SLPC (b) and SAPC (c). In each panel, native lipid is the bottom, red spectrum and chlorohydrin is the top, blue spectrum. In the native spectra, the multiplet labelled (1) at $5.3 \mathrm{ppm}$ corresponds to the vinyl protons $(\mathrm{CH}=\mathrm{CH})$, the multiplet (2) at $2.8 \mathrm{ppm}$ is bis-allylic protons $\left(=\mathrm{CCH}_{2} \mathrm{C}=\right)$ which is absent in SOPC, and the multiplet (3) corresponds to allylic protons $\left(\mathrm{CH}_{2} \mathrm{C}=\right)$. These signals all disappear on formation of chlorohydrins indicating the loss of the double bonds, and other signals corresponding to $\mathrm{CHs}$ and $\mathrm{CH}_{2}$ s adjacent to the substituted carbons appear (4 \& 5). Phospholipids were prepared in 1:1:2:10 pyridine- $d_{5}: D C l$ in $D_{2} \mathrm{O}$ : methanol- $\mathrm{d}_{4}$ : chloroform-d; spectra were acquired at $270 \mathrm{MHz}$ and referenced to tetramethylsilane at $0 \mathrm{ppm}$. 
(A)

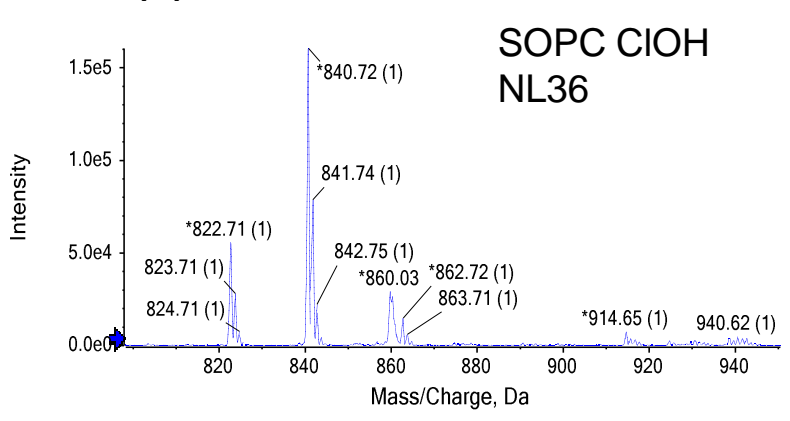

(B)

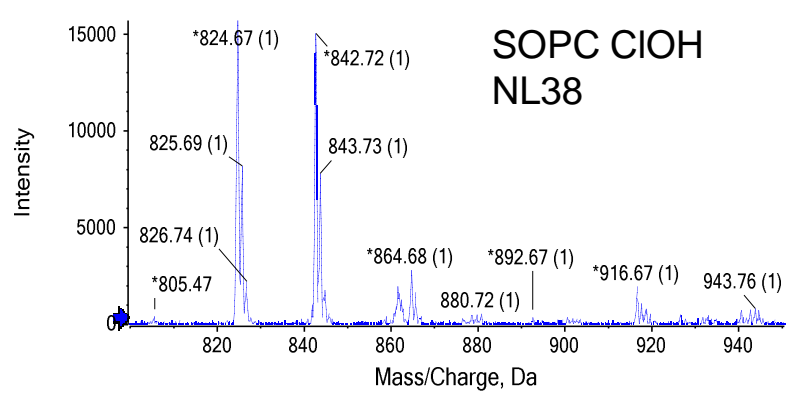

(C)

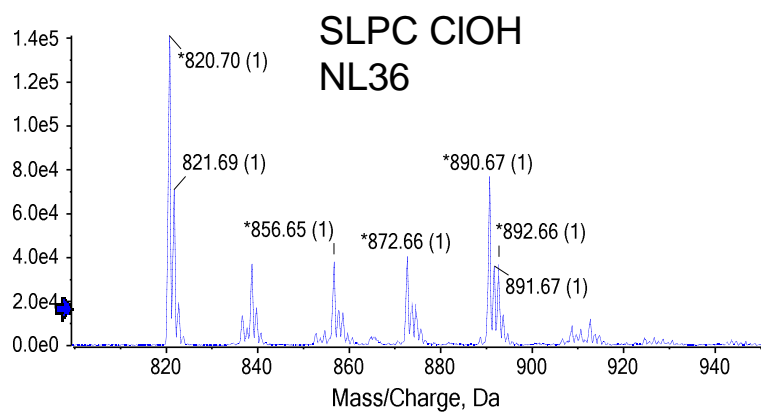

(D)

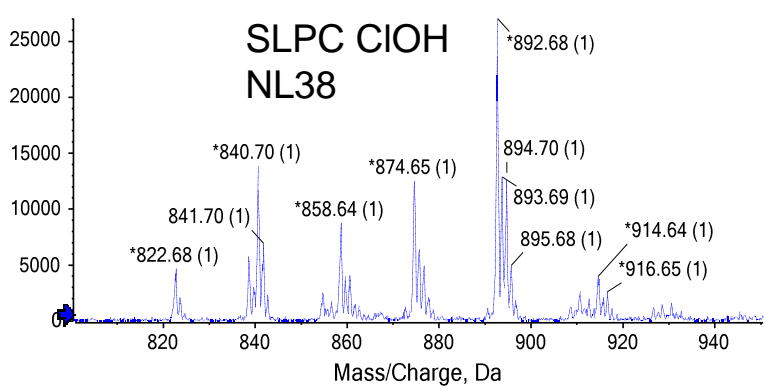

(E)

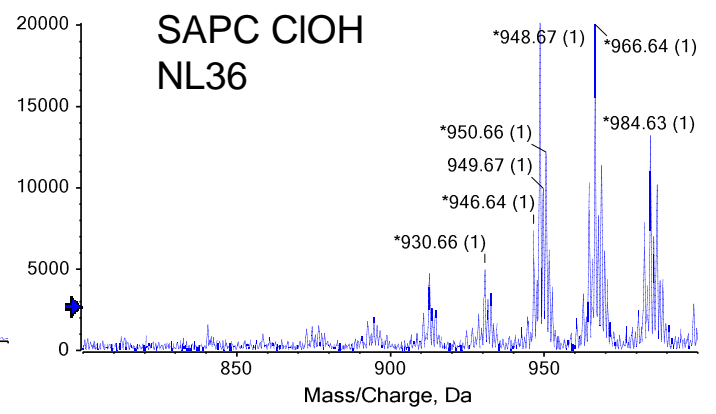

(F)

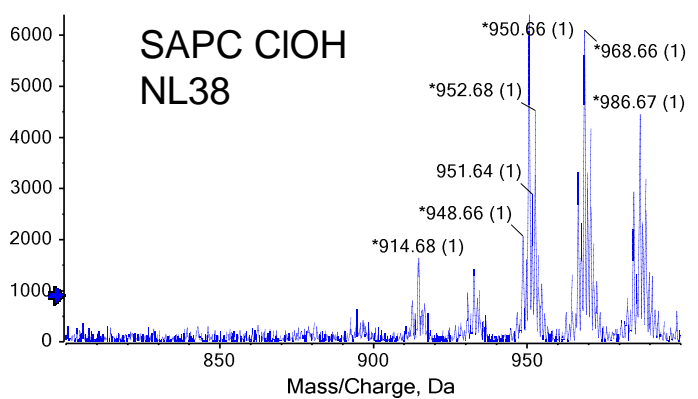

Supporting Figure 2. MSMS data for phospholipid chlorohydrins showing characterization by neutral loss (NL) of 36 and $38 \mathrm{Da}$, corresponding to loss of $\mathrm{H}^{35} \mathrm{Cl}$ and $\mathrm{H}^{37} \mathrm{Cl}$ respectively. Panels $\mathrm{A} \& \mathrm{~B}$ show SOPC mono-chlorohydrin at $\mathrm{m} / \mathrm{z} 840$ and 842 respectively for the $\mathrm{HO}^{35} \mathrm{Cl}$ and $\mathrm{HO}^{37} \mathrm{Cl}$ products. Panels C \& D show SLPC chlorohydrins with the bis-chlorohydrins at $\mathrm{m} / \mathrm{z} 890$ and 892. Panels E \& F show multiple SAPC chlorohydrins, although the tetra-chlorohydrin cannot be observed as the top instrument $\mathrm{m} / \mathrm{z}$ is 1000. All chlorohydrin show the presence of dehydration products under the fragmentation conditions used, as described previously (Pitt and Spickett, 2008, Biochem Soc Trans). No significant formation of lysolipids was observed with SOPC and SLPC, but a small amount $(\sim 10 \%)$ of lysolipid at $\mathrm{m} / \mathrm{z} 524$ did occur. MS analysis was carried out using direct infusion onto an ABSciex 5500QTrap, essentially as described previously (Spickett et al., 2011, FRBM). 

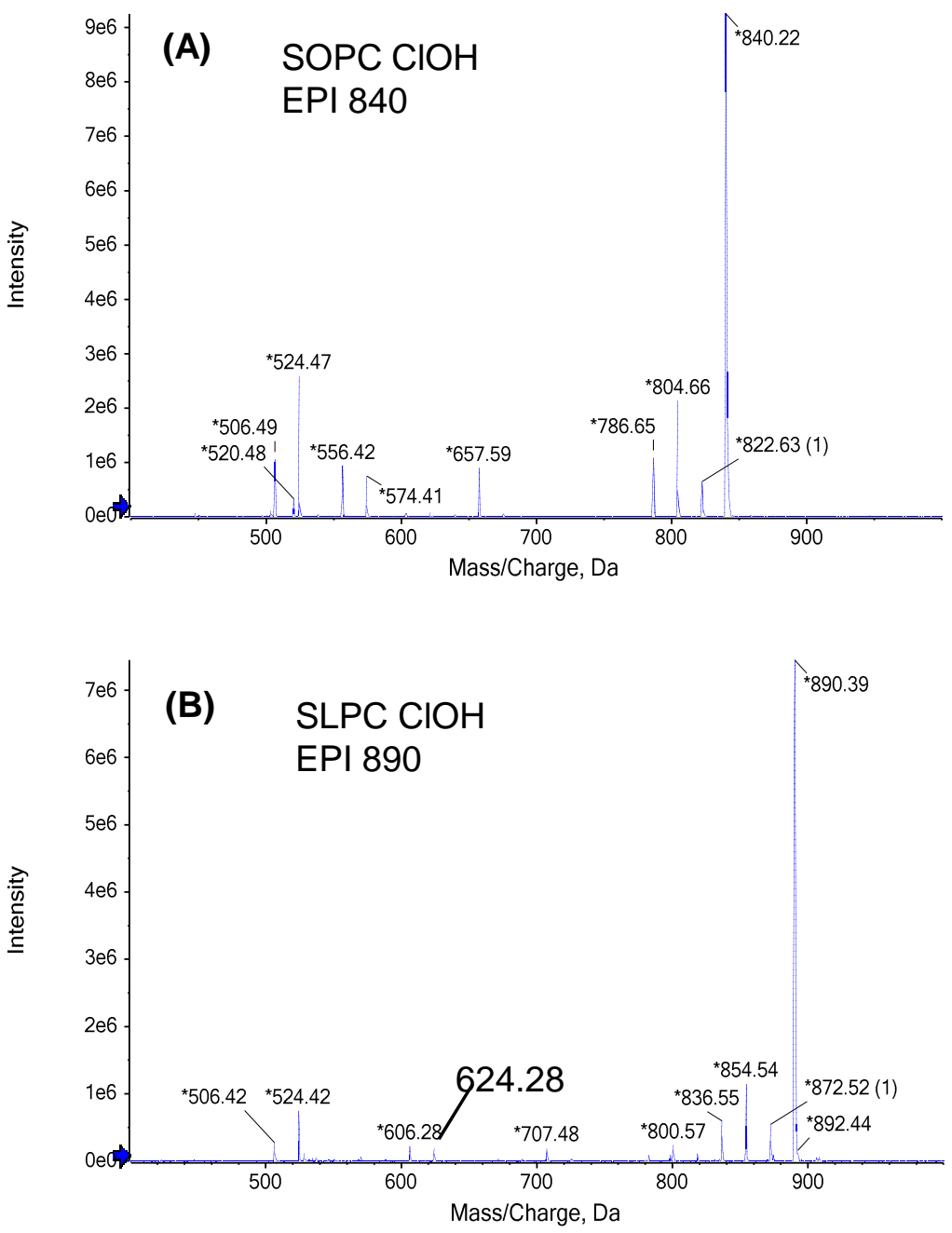

Supporting Figure 3. MSMS fragmentation profile of SOPC mono-chlorohydrin at $\mathrm{m} / \mathrm{z} 840$ (A) and SLPC bischlorohydrin at $\mathrm{m} / \mathrm{z} 890(\mathrm{~B})$. SOPC chlorohydrin shows fragment ions at $\mathrm{m} / \mathrm{z} 524$ and 506 , corresponding to the lysolipid retaining stearate, and peaks at $\mathrm{m} / \mathrm{z} 574$ and 556 for lysolipid retaining the chlorohydrin modified chain. SLPC chlorohydrin shows the same fragment ions for the lysolipid retaining stearate, and peaks at $\mathrm{m} / \mathrm{z} 624$ and 606 for lysolipid retaining the bis-chlorohydrin modified chain. Both parent ions also show characteristic loss of water (18 Da) and $\mathrm{HCl}(36 \mathrm{Da})$. MS analysis was carried out using direct infusion onto an ABSciex 5500QTrap, essentially as described previously (Spickett et al., 2011, FRBM). 


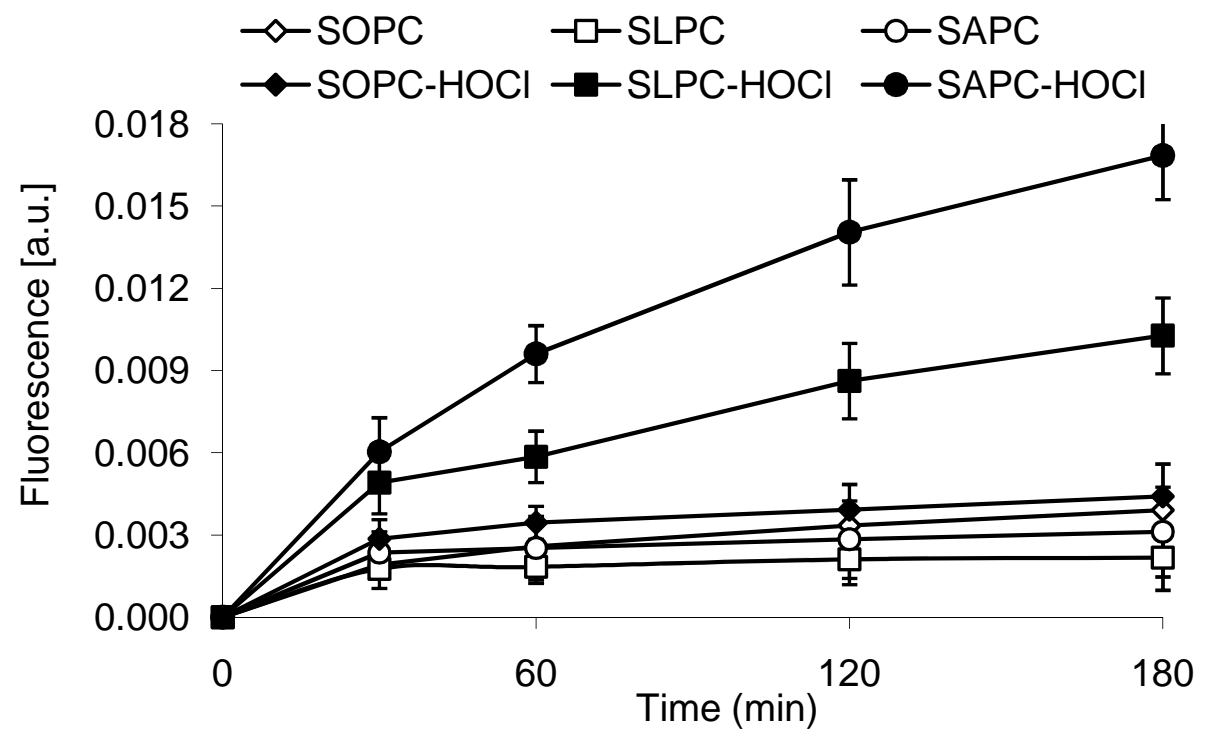

Supporting Figure 4. Incorporation of liposomes to HUVEC-ST cells

The fusion of liposomes labeled with NBD with cells was determined on the basis of cell fluorescence measurement at selected incubation points. Each result shows mean $\pm S E M, n=3$. Significant effects: Non-chloro vs Chloro $F=46.8$ ( $p<0.001)$, Lipids $F=10.56(p<0.001)$, Time $F=5.40(p<0.01)$, Fisher's PLSD $=0.0014$ 
Supplementary Tables. Statistical analysis by 3-factor ANOVA for all the figures. Univariate tests of Significance for Data Vial (prz1) Sigma-restricted parameterization with effective hypothesis decomposition. $\mathrm{DF}=$ Degrees of freedom; MS = Mean squares; F = Fisher ratio (treatment variance/baseline variance) $; \mathrm{p}=$ probability.

\begin{tabular}{|c|c|c|c|c|}
\hline \multicolumn{5}{|c|}{$\begin{array}{l}\text { Suppl. Table 1A. Statistical analysis for Fig. 1A (cytotoxicity of } \\
\text { Non-chloro \& Chloro lipids) }\end{array}$} \\
\hline & DF & MS & F & $\mathrm{p}$ \\
\hline Intercept & 1 & 1321379 & 11959.43 & 0.000000 \\
\hline $\mathrm{NC} / \mathrm{C}$ & 1 & 38976 & 352.76 & 0.000000 \\
\hline Lipids & 2 & 5850 & 52.95 & 0.000000 \\
\hline Conc & 5 & 11032 & 99.84 & 0.000000 \\
\hline NC/C*Lipids & 2 & 2967 & 26.85 & 0.000000 \\
\hline NC/C*Conc & 5 & 3007 & 27.21 & 0.000000 \\
\hline Lipids*Conc & 10 & 294 & 2.66 & 0.004653 \\
\hline NC/C*Lipids*Conc & 10 & 138 & 1.25 & 0.262618 \\
\hline Error & 180 & 110 & & \\
\hline
\end{tabular}

Suppl. Table 1B. Statistical analysis for Fig. 1C (Flow cytometry analysis of Living cells at $24 \mathrm{hr}$ )

\begin{tabular}{|l|l|l|l|l|}
\hline & DF & MS & F & p \\
\hline Intercept & 1 & 579257 & 86031 & 0.000000 \\
\hline NC/C & 1 & 618.5 & 91.85 & 0.000000 \\
\hline Lipids & 2 & 235.2 & 34.94 & 0.000000 \\
\hline Conc & 2 & 1156.2 & 171.72 & 0.000000 \\
\hline NC/C*Lipids & 2 & 100.7 & 14.95 & 0.000007 \\
\hline NC/C*Conc & 2 & 240.5 & 35.71 & 0.000000 \\
\hline Lipids*Conc & 4 & 89.7 & 13.32 & 0.000000 \\
\hline NC/C*Lipids*Conc & 4 & 35.6 & 5.28 & 0.001153 \\
\hline Error & 54 & 6.7 & & \\
\hline
\end{tabular}

Suppl. Table 1C. Statistical analysis for Fig. 1C (Flow cytometry analysis of Apoptosis at $\mathbf{2 4} \mathbf{~ h r}$ )

\begin{tabular}{|l|l|l|l|l|}
\hline & DF & MS & F & p \\
\hline Intercept & 1 & 4532.8 & 594.66 & 0.000000 \\
\hline NC/C & 1 & 428.61 & 56.23 & 0.000000 \\
\hline Lipids & 2 & 207.54 & 27.23 & 0.000000 \\
\hline Conc & 2 & 858.78 & 112.66 & 0.000000 \\
\hline NC/C*Lipids & 2 & 81.89 & 10.74 & 0.000118 \\
\hline NC/C*Conc & 2 & 152.43 & 19.99 & 0.000000 \\
\hline Lipids*Conc & 4 & 71.81 & 9.42 & 0.000008 \\
\hline NC/C*Lipids*Conc & 4 & 28.12 & 3.69 & 0.009980 \\
\hline Error & 54 & 7.62 & & \\
\hline & & & &
\end{tabular}

\begin{tabular}{|l|l|l|l|l|}
\hline \multicolumn{5}{|l}{$\begin{array}{l}\text { Suppl. Table 1E. Statistical analysis for Fig. 1D (mitochondrial } \\
\text { potential) }\end{array}$} \\
\hline & DF & MS & F & p \\
\hline Intercept & 1 & 153.327 & 9911.68 & 0.000000 \\
\hline NC/C & 1 & 0.479 & 30.937 & 0.000000 \\
\hline Lipids & 2 & 0.109 & 7.024 & 0.001214 \\
\hline Conc & 4 & 0.608 & 39.281 & 0.000000 \\
\hline NC/C*Lipids & 2 & 0.043 & 2.804 & 0.063773 \\
\hline NC/C*Conc & 4 & 0.042 & 2.692 & 0.033252 \\
\hline Lipids*Conc & 8 & 0.021 & 1.355 & 0.220972 \\
\hline NC/C*Lipids*Conc & 8 & 0.006 & 0.409 & 0.914148 \\
\hline Error & 150 & 0.016 & & \\
\hline
\end{tabular}

Suppl. Table 1D. Statistical analysis for Fig. 1C (Flow cytometry analysis of Necrosis at $24 \mathrm{hr}$ )

\begin{tabular}{|l|l|l|l|l|}
\hline & DF & MS & F & $\mathrm{p}$ \\
\hline Intercept & 1 & 423.352 & 166.871 & 0.000000 \\
\hline NC/C & 1 & 11.948 & 4.709 & 0.034415 \\
\hline Lipids & 2 & 0.071 & 0.028 & 0.972432 \\
\hline Conc & 2 & 42.059 & 16.578 & 0.000002 \\
\hline NC/C*Lipids & 2 & 3.423 & 1.349 & 0.268028 \\
\hline NC/C*Conc & 2 & 6.680 & 2.633 & 0.081062 \\
\hline Lipids*Conc & 4 & 0.185 & 0.073 & 0.990076 \\
\hline NC/C*Lipids*Conc & 4 & 2.247 & 0.886 & 0.478692 \\
\hline Error & 54 & 2.537 & & \\
\hline
\end{tabular}




\begin{tabular}{|l|l|l|l|l|}
\hline \multicolumn{5}{|l}{$\begin{array}{l}\text { Suppl. Table 2A. Statistical analysis for Fig. 2A (Caspase-3 } \\
\text { activity at } 6 \text { hr) }\end{array}$} \\
\hline & DF & & F & p \\
\hline Intercept & 1 & 878217.3 & 3158.11 & 0.000000 \\
\hline NC/C & 1 & 12775.9 & 45.94 & 0.000000 \\
\hline Lipids & 2 & 8622.0 & 31.01 & 0.000000 \\
\hline Conc & 2 & 20619.5 & 74.15 & 0.000000 \\
\hline NC/C*Lipids & 2 & 2247.4 & 8.08 & 0.001261 \\
\hline NC/C*Conc & 2 & 5816.9 & 20.92 & 0.000001 \\
\hline Lipids*Conc & 4 & 3518.9 & 12.65 & 0.000002 \\
\hline NC/C*Lipids*Conc & 4 & 744.4 & 2.68 & 0.047240 \\
\hline Error & 36 & 278.1 & & \\
\hline
\end{tabular}

\begin{tabular}{|l|l|l|l|l|}
\hline $\begin{array}{l}\text { Suppl. Table 2B. Statistical analysis for Fig. 2B (Caspase-7 } \\
\text { activity at 6 hr) }\end{array}$ & DF & MS & F & p \\
\hline & 1 & 484764.5 & 8681.90 & 0.000000 \\
\hline Intercept & 1 & 1060.2 & 18.99 & 0.000379 \\
\hline NC/C & 2 & 3045.7 & 54.55 & 0.000000 \\
\hline Lipids & 2 & 5486.0 & 98.25 & 0.000000 \\
\hline Conc & 2 & 404.5 & 7.24 & 0.004919 \\
\hline NC/C*Lipids & 2 & 1021.7 & 18.30 & 0.000046 \\
\hline NC/C*Conc & 4 & 1054.5 & 18.89 & 0.000003 \\
\hline Lipids*Conc & 4 & 146.4 & 2.62 & 0.069229 \\
\hline NC/C*Lipids*Conc & 18 & 55.8 & & \\
\hline Error & & & &
\end{tabular}

Suppl. Table 3A. Statistical analysis for Fig. 3 (\% of cells in $\mathrm{G}_{\mathbf{0}} / \mathrm{G}_{\mathbf{1}}$ phase)

\begin{tabular}{|l|l|l|l|l|}
\hline & DF & MS & F & p \\
\hline Intercept & 1 & 65798.6 & 15751.9 & 0.000000 \\
\hline NC/C & 1 & 346.2 & 82.9 & 0.000001 \\
\hline Lipids & 2 & 73.3 & 17.5 & 0.000274 \\
\hline Conc & 1 & 440.4 & 105.4 & 0.000000 \\
\hline NC/C*Lipids & 2 & 51.1 & 12.2 & 0.001271 \\
\hline NC/C*Conc & 1 & 346.2 & 82.9 & 0.000001 \\
\hline Lipids*Conc & 2 & 73.3 & 17.5 & 0.000274 \\
\hline NC/C*Lipids*Conc & 2 & 51.1 & 12.2 & 0.001271 \\
\hline Error & 12 & 4.2 & & \\
\hline
\end{tabular}

Suppl. Table 3C. Statistical analysis for Fig. 3 (\% of cells in $\mathbf{G}_{2} / \mathbf{M}$ phase)

\begin{tabular}{|l|l|l|l|l|}
\hline & DF & MS & F & p \\
\hline Intercept & 1 & 6416.57 & 4963.75 & 0.000000 \\
\hline NC/C & 1 & 60.93 & 47.14 & 0.000017 \\
\hline Lipids & 2 & 10.33 & 7.99 & 0.006226 \\
\hline Conc & 1 & 99.74 & 77.16 & 0.000001 \\
\hline NC/C*Lipids & 2 & 7.30 & 5.65 & 0.018674 \\
\hline NC/C*Conc & 1 & 60.93 & 47.14 & 0.000017 \\
\hline Lipids*Conc & 2 & 10.33 & 7.99 & 0.006226 \\
\hline NC/C*Lipids*Conc & 2 & 7.30 & 5.65 & 0.018674 \\
\hline Error & 12 & 1.29 & & \\
\hline
\end{tabular}

Suppl. Table 3B. Statistical analysis for Fig. 3 (\% of cells in $\mathrm{S}$ phase)

\begin{tabular}{|l|l|l|l|l|}
\hline & DF & MS & F & p \\
\hline Intercept & 1 & 23495.3 & 4882.07 & 0.000000 \\
\hline NC/C & 1 & 116.66 & 24.24 & 0.000352 \\
\hline Lipids & 2 & 29.15 & 6.06 & 0.015193 \\
\hline Conc & 1 & 120.97 & 25.14 & 0.000302 \\
\hline NC/C*Lipids & 2 & 20.01 & 4.16 & 0.042460 \\
\hline NC/C*Conc & 1 & 116.66 & 24.24 & 0.000352 \\
\hline Lipids*Conc & 2 & 29.15 & 6.06 & 0.015193 \\
\hline NC/C*Lipids*Conc & 2 & 20.01 & 4.16 & 0.042460 \\
\hline Error & 12 & 4.81 & & \\
\hline
\end{tabular}


Suppl. Table 4A. Statistical analysis for Fig. 4A (Cellular ROS production measured by dihydrorhodamine 123)

\begin{tabular}{|l|l|l|l|l|}
\hline & DF & MS & F & $\mathrm{p}$ \\
\hline Intercept & 1 & 595766.3 & 2810.5 & 0.000000 \\
\hline NC/C & 1 & 17899.7 & 84.4 & 0.000000 \\
\hline Lipids & 2 & 3850.1 & 18.2 & 0.000048 \\
\hline Conc & 2 & 9229.8 & 43.5 & 0.000000 \\
\hline NC/C*Lipids & 2 & 1721.6 & 8.1 & 0.003064 \\
\hline NC/C*Conc & 2 & 5926.4 & 27.9 & 0.000003 \\
\hline Lipids*Conc & 4 & 1170.1 & 5.5 & 0.004428 \\
\hline NC/C*Lipids*Conc & 4 & 499.0 & 2.4 & 0.092756 \\
\hline Error & 18 & 212.0 & & \\
\hline
\end{tabular}

\begin{tabular}{|l|l|l|l|l|}
\hline $\begin{array}{l}\text { Suppl. Table 4C. Statistical analysis for Fig. 4C (Protection of } \\
\text { pyrogallol red in cell lysates) }\end{array}$ \\
\hline & DF & MS & F & p \\
\hline Intercept & 1 & 903558.5 & 2026.959 & 0.000000 \\
\hline NC/C & 1 & 2740.3 & 6.147 & 0.020575 \\
\hline Lipids & 2 & 1635.3 & 3.668 & 0.040727 \\
\hline Conc & 1 & 11245.1 & 25.226 & 0.000039 \\
\hline NC/C*Lipids & 2 & 13.2 & 0.030 & 0.970904 \\
\hline NC/C*Conc & 1 & 2740.3 & 6.147 & 0.020575 \\
\hline Lipids*Conc & 2 & 1635.3 & 3.668 & 0.040727 \\
\hline NC/C*Lipids*Conc & 2 & 13.2 & 0.030 & 0.970904 \\
\hline Error & 24 & 445.8 & & \\
\hline
\end{tabular}

\begin{tabular}{|c|c|c|c|c|}
\hline \multicolumn{5}{|c|}{$\begin{array}{l}\text { Suppl. Table 4E. Statistical analysis for Fig. 4E (Glutathione } \\
\text { concentration in cell lysates) }\end{array}$} \\
\hline & DF & MS & $\mathrm{F}$ & $\mathrm{p}$ \\
\hline Intercept & 1 & 164861.7 & 22014.84 & 0.000000 \\
\hline $\mathrm{NC} / \mathrm{C}$ & 1 & 823.1 & 109.91 & 0.000000 \\
\hline Lipids & 2 & 333.5 & 44.54 & 0.000000 \\
\hline Conc & 4 & 478.5 & 63.90 & 0.000000 \\
\hline NC/C*Lipids & 2 & 193.9 & 25.89 & 0.000000 \\
\hline $\mathrm{NC} / \mathrm{C}{ }^{*}$ Conc & 4 & 66.2 & 8.84 & 0.000011 \\
\hline Lipids*Conc & 8 & 40.8 & 5.45 & 0.000036 \\
\hline NC/C*Lipids*Conc & 8 & 15.6 & 2.08 & 0.052156 \\
\hline Error & 60 & 7.5 & & \\
\hline
\end{tabular}

Suppl. Table 4B. Statistical analysis for Fig. 4B (Mitochondrial ROS production measured by MitoSOX red)

\begin{tabular}{|l|l|l|l|l|}
\hline & DF & MS & F & p \\
\hline Intercept & 1 & 862992 & 16425.5 & 0.000000 \\
\hline NC/C & 1 & 20087.8 & 382.3 & 0.000000 \\
\hline Lipids & 2 & 7632.6 & 145.3 & 0.000000 \\
\hline Conc & 2 & 17170.2 & 326.8 & 0.000000 \\
\hline NC/C*Lipids & 2 & 4587.6 & 87.3 & 0.000000 \\
\hline NC/C*Conc & 2 & 5370.8 & 102.2 & 0.000000 \\
\hline Lipids*Conc & 4 & 2100.4 & 39.9 & 0.000000 \\
\hline NC/C*Lipids*Conc & 4 & 1212.8 & 23.1 & 0.000000 \\
\hline Error & 36 & 52.5 & & \\
\hline
\end{tabular}

Suppl. Table 4D. Statistical analysis for Fig. 4D (Antioxidant capacity of cell lysates by ABTS decolorization)

\begin{tabular}{|l|l|l|l|l|}
\hline & DF & MS & F & p \\
\hline Intercept & 1 & 158687.3 & 10052.51 & 0.000000 \\
\hline NC/C & 1 & 85.4 & 5.41 & 0.038341 \\
\hline Lipids & 2 & 184.7 & 11.70 & 0.001517 \\
\hline Conc & 1 & 1479.3 & 93.71 & 0.000001 \\
\hline NC/C*Lipids & 2 & 47.4 & 3.01 & 0.087456 \\
\hline NC/C*Conc & 1 & 85.4 & 5.41 & 0.038341 \\
\hline Lipids*Conc & 2 & 184.7 & 11.70 & 0.001517 \\
\hline NC/C*Lipids*Conc & 2 & 47.4 & 3.01 & 0.087456 \\
\hline Error & 12 & 15.8 & & \\
\hline
\end{tabular}

Suppl. Table 4F. Statistical analysis for Fig. 4F (Phosphorylation in p38 kinase)

\begin{tabular}{|l|l|l|l|l|}
\hline & DF & MS & F & $p$ \\
\hline Intercept & 1 & 10.73873 & 790.6407 & 0.000000 \\
\hline NC/C & 1 & 0.30803 & 22.6784 & 0.000076 \\
\hline Lipids & 2 & 0.38376 & 28.2544 & 0.000000 \\
\hline Conc & 1 & 0.69723 & 51.3333 & 0.000000 \\
\hline NC/C*Lipids & 2 & 0.13160 & 9.6894 & 0.000823 \\
\hline NC/C*Conc & 1 & 0.30803 & 22.6784 & 0.000076 \\
\hline Lipids*Conc & 2 & 0.38376 & 28.2544 & 0.000000 \\
\hline NC/C*Lipids*Conc & 2 & 0.13160 & 9.6894 & 0.000823 \\
\hline Error & 24 & 0.01358 & & \\
\hline
\end{tabular}




\begin{tabular}{|l|l|l|l|l|}
\hline $\begin{array}{l}\text { Suppl. Table 5. Statistical analysis for Supp. Fig. 4 } \\
\text { (Incorporation of liposomes into HUVEC-ST cells) }\end{array}$ \\
\hline & DF & MS & F & p \\
\hline Intercept & 1 & 0.002026 & 182.964 & 0.000000 \\
\hline NC/C & 1 & 0.000518 & 46.774 & 0.000000 \\
\hline Lipids & 2 & 0.000117 & 10.567 & 0.000157 \\
\hline Time & 3 & 0.000060 & 5.400 & 0.002772 \\
\hline NC/C*Lipids & 2 & 0.000115 & 10.401 & 0.000177 \\
\hline NC/C*Time & 3 & 0.000039 & 3.541 & 0.021346 \\
\hline Lipids*Time & 6 & 0.000008 & 0.682 & 0.664949 \\
\hline NC/C*Lipids*Time & 6 & 0.000015 & 1.321 & 0.266076 \\
\hline Error & 48 & 0.000011 & & \\
\hline
\end{tabular}

